\title{
Polyphenols as Promising Drugs against Main Breast Cancer Signatures
}

\author{
María Losada-Echeberría ${ }^{1}$ (1), María Herranz-López ${ }^{1}$, Vicente Micol ${ }^{1,2}$ \\ and Enrique Barrajón-Catalán ${ }^{1, *}$ (i) \\ 1 Institute of Molecular and Cell Biology (IBMC), Miguel Hernández University (UMH), \\ Avda. Universidad s/n, Elche 03202, Spain; mlosada@umh.es (M.L.-E.); mherranz@umh.es (M.H.-L.); \\ vmicol@umh.es (V.M.) \\ 2 CIBER, Fisiopatología de la Obesidad y la Nutrición, CIBERobn, Instituto de Salud Carlos III \\ (CB12/03/30038), Palma de Mallorca 07122, Spain \\ * Correspondence: e.barrajon@umh.es; Tel.: +34-965-222-586
}

Received: 4 October 2017; Accepted: 3 November 2017; Published: 7 November 2017

\begin{abstract}
Breast cancer is one of the most common neoplasms worldwide, and in spite of clinical and pharmacological advances, it is still a clinical problem, causing morbidity and mortality. On the one hand, breast cancer shares with other neoplasms some molecular signatures such as an imbalanced redox state, cell cycle alterations, increased proliferation and an inflammatory status. On the other hand, breast cancer shows differential molecular subtypes that determine its prognosis and treatment. These are characterized mainly by hormone receptors especially estrogen receptors (ERs) and epidermal growth factor receptor 2 (HER2). Tumors with none of these receptors are classified as triple negative breast cancer (TNBC) and are associated with a worse prognosis. The success of treatments partially depends on their specificity and the adequate molecular classification of tumors. New advances in anticancer drug discovery using natural compounds have been made in the last few decades, and polyphenols have emerged as promising molecules. They may act on various molecular targets because of their promiscuous behavior, presenting several physiological effects, some of which confer antitumor activity. This review analyzes the accumulated evidence of the antitumor effects of plant polyphenols on breast cancer, with special attention to their activity on ERs and HER2 targets and also covering different aspects such as redox balance, uncontrolled proliferation and chronic inflammation.
\end{abstract}

Keywords: breast cancer; polyphenols; luminal; TNBC; redox balance; apoptosis; autophagy; inflammation; ER; HER2

\section{Introduction}

Nowadays, cancer is one of the main causes of mortality worldwide. In 2012, 14 million new cases were diagnosed, and there were 8.2 million cancer-related deaths [1]. Breast cancer is the most common tumor in occidental women; one in eight women will have a breast tumor during their lifetime, and every year, up to 1.4 million new cases are diagnosed worldwide [1]. An annual mortality rate of about 450,000 is estimated, which accounts for $20-30 \%$ of all tumors.

Currently, treatments are based mainly on two molecular markers: hormone receptors and epidermal growth factor receptor 2 (HER2). The expression of these molecular markers determines both prognosis and treatment. Although new therapies against breast cancer have been able to reduce mortality, the prognosis, especially in the more advanced stages, remains unpromising, and therefore, further research in this field is needed [2]. The main advances have been obtained for HER2 positive tumors where monoclonal antibodies such as trastuzumab (Herceptin ${ }^{\circledR}$ ) have improved prognosis in HER2 overexpressing tumors [3]. Unfortunately, even in these cases, resistance is also frequent, leading 
to nonspecific therapeutic options. In addition, approximately 10-20\% of breast tumors are considered triple negative, which implies that no specific therapy is available, and only classic chemotherapy may be applied.

In this clinical scenario, new efforts have been made to obtain new drugs for breast cancer treatment leading to several promising molecules [4]. However, new molecules are still required. Natural compounds from different origins such as vegetal [5], microbial [6] and marine [7] species are a source of new molecules demonstrating activity against cancer and other diseases. These compounds derive from the secondary metabolism of these organisms and have been selected by nature through evolution. Between natural compounds, polyphenols have emerged as one of the main families of compounds with potential biological activity in many diseases such as cancer [8-13], diabetes [14,15], inflammation [16-19], obesity-related diseases [20], neurodegenerative disorders [21-23], bacterial [24-27] and viral infections [28,29] or cardiovascular diseases [30]. In addition, they possess a relevant antioxidant activity [24,31-35], which is the basis of part of their biological activity.

Polyphenols are widely distributed in fruits, vegetables, tea, essential oils and cereals; their molecular structure is characterized by the presence of one or more phenolic rings substituted with at least one hydroxyl group. Different classes and subclasses of polyphenols generate a large structural variability that is characterized by the number of phenolic rings they possess and the moieties that substitute their aromatic rings (see http://phenol-explorer.eu/compounds/classification for an updated classification). The main groups of polyphenols are: phenolic acids, flavonoids, stilbenes and lignans (Figure 1).

\section{Polyphenols}

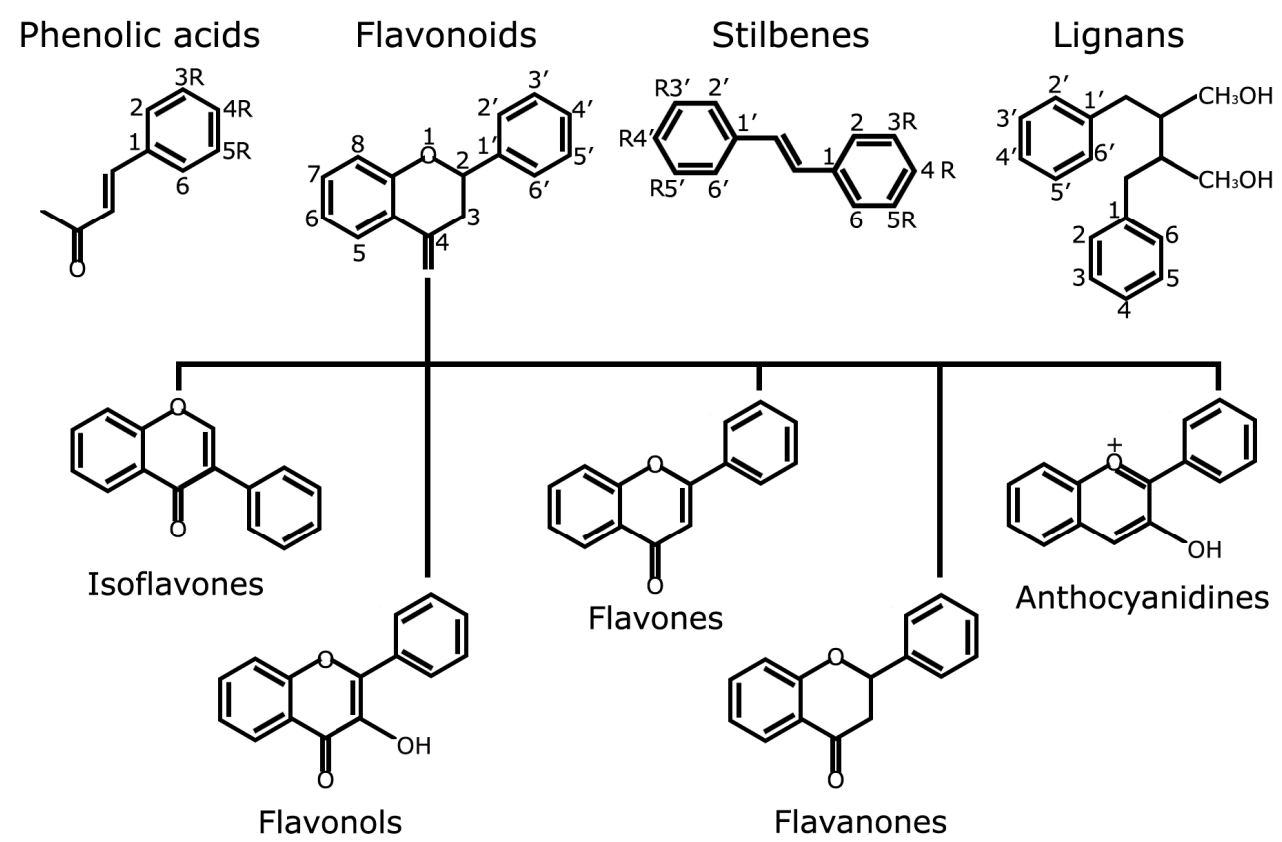

Figure 1. Polyphenols structure and classification.

As mentioned above, some polyphenols have demonstrated anticancer activity, showing biological activity against most of the main cancer molecular targets such as kinases, pre- and anti-apoptotic proteins, enzymes that regulate energy metabolism and regulatory proteins linked to proliferation and signaling pathways [36]. Their broad activity may be attributed to several mechanisms, including the interaction and modulation of a wide range of proteins, enzymes and membrane receptors, regulation of gene expression, apoptosis induction, vasodilation and modulation of cell pathways [37-42]. In addition, polyphenols have preventive effects against tumor initiation through numerous 
mechanisms, such as the avoidance of genotoxic molecule formation, the blockade of mutagenic transforming enzyme activity [43], the regulation of Phase I and II enzymes, such as cytochrome P450s (CYP) [44] and S-transferase (GST) [45], as well as preventing DNA damage [46,47].

For all these reasons, new treatments based on polyphenolic compounds are being studied as an alternative and/or adjuvant therapies in these pathologies using different models [21]. Potential benefits of their dietary intake on human health and, more specifically, on cancer risk (including breast cancer) have been also reviewed $[48,49]$. Specifically, for breast cancer, interesting results have been obtained with a mixture of tea extract and quercetin [50], with Pinus radiata [51], Indian lotus [52], Hypogymnia physodes lichen [53], Morinda citrifolia [54] or with olive leaf extracts [55-58], among others.

This review describes the different breast cancer types, molecular biomarkers and their main treatments. A compilation of the main molecular breast cancer targets and the use of polyphenols to address them is reviewed, covering different aspects such as redox balance, uncontrolled proliferation and chronic inflammation, with particular interest in ER (estrogen receptor) and HER2 and the use of polyphenols to modulate their pathways.

\section{Breast Cancer Biomarkers Determine Both Prognosis and Treatment}

The identification of molecular biomarkers plays a significant role in the diagnosis and prognosis of breast cancer. They represent therapeutic targets, and their expression is used to classify cancers according to the different molecular subtypes (Table 1). The major biomarkers of breast cancer include the hormonal estrogen and progesterone receptors (ER and PR) and HER2/ERBB2 and, with less relevance, Ki-67 protein [59]. These markers have been extensively studied, and their expression correlates with differences in tumor behavior and patient response to treatments [60,61]:

- Hormone receptors, ERs and PR, are the main factors responsible for hormone response. Breast cancer is a hormone-dependent tissue, and this response is controlled by these receptors [62,63]. ER and PR expression confer a better prognosis and are the basis of hormonal therapy.

- HER2 is a membrane receptor involved in cell proliferation signal transduction. It is present in normal cells and in most tumors, but in $5-15 \%$ of breast tumors is overexpressed, increasing tumor aggressiveness [59]. These tumors are very often sensitive to treatment with anti-HER2 treatments, such as humanized monoclonal antibodies or specific inhibitors [64].

- Ki-67: is a protein marker that can be only detected in proliferating cells and currently is used to rate tumor proliferation, particularly lymphomas, breast, endocrine and brain cancers [65]. Indeed, Ki-67 contributes greatly to the Oncotype score [66]. Tumors with high proliferation rates $(>15 \%)$ have a poor prognosis [65].

Using these molecular markers, breast cancer can be divided into four major molecular subtypes: Luminal A, Luminal B, HER2 type and triple negative breast cancer (TNBC) [67-69]. This division determines treatment as shown in Table 1. Overexpression of HER2 is related to the lack of expression of hormone receptors in most cases. The same situation occurs with Ki67, which is usually elevated in cells that do not express these receptors. Between Ki67 and HER2, no relationship has been found.

Table 1. Breast cancer molecular subtypes and their main treatments. Representative cell lines for each subtype are also shown.

\begin{tabular}{cccccc}
\hline Subtype & ER/PR & HER2 & Ki67 & Treatment & Cell lines \\
\hline Luminal A & $+/+$ & - & $<15 \%$ & Antihormonal & MCF7, T47D \\
Luminal B & $+/+$ & $-/+$ & $>15 \%$ & Antihormonal & BT474 \\
HER2-type & $-/-$ & + & & Anti-HER2 & SkBr3, AU565 \\
TNBC & $-/-$ & $-/-$ & $>15 \%$ & Chemotherapy & MDA-MB231 \\
\hline
\end{tabular}

Luminal A tumors are hormone dependent, with hormone receptors positive expression (ER/PR-positive). They are HER2 negative and present one or two tumor grades. They represent 
$30-70 \%$ of breast cancers [70-72] and have the best prognosis, with high survival and low recurrence rates [73-75].

Luminal B tumors tend to be ER/PR-positive. They can be HER2-negative or positive; in this last case, some authors consider it as a new sub-type called Luminal C [76], but this classification is not widespread. They are also characterized by a higher tumor grade, a larger tumor size and a positive lymph node dissemination. Patients with Luminal B tumors are usually diagnosed at more advanced ages than in cases with Luminal A $[75,77]$. Compared to Luminal A tumors, they also tend to have factors that lead to a poorer prognosis, mainly an increase in Ki67 protein of 15-20\% [78,79]. The prevalence of Luminal B tumors is approximately 10-20\% [70-72] and still shows high survival rates, although not as high as those of Luminal A tumors [75]. Treatments for both Luminal A and B are based on hormone therapy regimens [80], which is based on the use of SERMs (selective estrogen receptor modulators) such as tamoxifen or fulvestrant and aromatase inhibitors like anastrozole, exemestane and letrozole [81].

HER2-type tumors are characterized by being ER/PR-negative, overexpressing HER2, having lymph node positive implication and present poorer tumor grade [74,75]. Patients with HER2 tumors are usually diagnosed at an earlier age than Luminal A and Luminal B [75]. Approximately $5-15 \%$ of breast cancers are HER2-positive [71,72] and can be treated with specific anti-HER2 drugs. This group includes monoclonal antibodies like trastuzumab and pertuzumab and specific HER2 inhibitors like lapatinib [64]. Before these drugs were available, HER2-type tumors had a rather poor prognosis [71,82].

TNBC encompasses all tumors that are negative for ER, PR and HER2. It is considered the most metastatic type of breast cancer and has highly invasive properties, is larger, has a poorer prognosis with a high probability of relapse, no response to hormonal therapy and has nodal involvement. Around 10-20\% of tumors correspond to triple negative tumors [70-72]. There are several approaches to counteract TNBC, but all based on classical chemotherapy using anthracyclines, taxanes, poly(ADP-ribose) polymerase protein inhibitors and platinum-containing chemotherapeutic agents [83].

\section{Breast Cancer Signatures and Polyphenols}

\subsection{Redox Balance}

Oxidative stress is caused by an imbalance between the production of reactive oxygen species (ROS) and the efficacy of the endogenous antioxidant system. Tissues are continuously exposed to free radicals derived from metabolism or due to external factors such as pollution or radiation [84-86]. In fact, ROS participate in physiological functions such as metabolism signaling and defense against infections $[87,88]$. However, uncontrolled ROS production or accumulation can induce lipid peroxidation, protein modifications and DNA damage. These events lead to membrane alterations, protein dysfunctions and genetic alterations, all of which are linked to carcinogenesis and tumor progression.

Balance between oxidant species and antioxidants (redox balance) is essential to maintain a healthy cell status. Breast cancer is characterized by a systemic prooxidant status [89], and an increased ROS presence is determinant for some relevant events such as tumor progression mediated by stromal cells [90]. However, ROS can play a dual role [91], not only in breast [92], but in all cancers. Cells have several mechanisms to transform and eliminate ROS and avoid their harmful effects, such as superoxide dismutase (SOD), catalase (CAT) or glutathione peroxidase (GTX) enzymes [93-95]. The synergistic action between these enzymes, vitamins and exogenous antioxidants such as polyphenols allows neutralizing free radicals and modulating cellular signaling [96].

Initially, increased ROS production leads to a pro-oncogenic situation as it provokes two crucial effects: mitochondrial dysfunction that conduces to protein oxidation, lipid peroxidation and DNA damage. On the other hand, once tumor cells have developed, an increase in ROS presence can lead to tumor cell death. This fact has been linked to some anticancer drugs such as doxorubicin and paclitaxel. 
Polyphenols can participate in these two situations. First, it is generally admitted that polyphenols are antioxidants and therefore counteract ROS production and inhibit oxidative DNA damage and mitochondrial dysfunction by acting as chemo-preventive agents [97,98]. For this reason, the preventive character of polyphenols acquired through diet in diseases such as cancer $[99,100]$, diabetes [101,102] or atherosclerosis $[103,104]$ has been studied.

However, there is increasing evidence suggesting that under certain conditions, polyphenols can act as prooxidants, leading to tumor cell death $[105,106]$. For example, it has been shown that in systems containing active redox metals such as copper, some polyphenols show prooxidant activity, catalyzing their redox cycle and leading to ROS formation $[107,108]$. Since copper levels in cancer cells compared to healthy cells are increased [109], this prooxidant mechanism would present preferential cytotoxicity against cancer cells, leaving the normal cells undamaged. This effect has been demonstrated using polyphenols like luteolin, apigenin, epigallocatechin-3-gallate and resveratrol [110].

\subsection{Uncontrolled Proliferation}

One of the main characteristics of tumor cells, no matter their origin, is their ability to grow and proliferate in an uncontrolled way. Cellular proliferation is mainly linked to cell cycle progression. This cycle shows different checkpoints in which the cell examines the internal and external signals and decides whether to proceed with cell division or not. This uncontrolled cell division is caused by a malfunction of these checkpoints in the cell cycle [111,112]. The most important regulators of the cell cycle are proteins called cyclins, enzymes called cyclin-dependent kinases (CDKs) and anaphase-promoting enzymatic complex (APC/C) $[113,114]$. In addition, the active CDK complexes are regulated by binding to $\mathrm{CDK}$ inhibitors (p21 and p27) and by other kinases and phosphatases, which control the cell cycle by balancing CDK activity. Variations in the concentration of these inhibitors can alter the normal sequence of the cell cycle as occurs in some tumors or in aged cells.

Polyphenols can act by modulating cyclins, Cdks or APC/C causing cell cycle arrest $[115,116]$. This cytostatic activity has been also studied in breast cancer, where some polyphenolic compounds have demonstrated their cytostatic activity. For example, ginnalins A-C induce cell cycle arrest in the $S$ and G2/M phases in colon cancer HCT-116 cells and breast cancer MCF-7 cells by decreasing cyclin A and D1 levels [117]. Green tea polyphenols induce cell cycle arrest at G1/G0 phase in breast cancer MCF-7 cells [118]. Polyphenolic extracts from hawthorn fruit have shown a cytostatic effect on MCF-7 breast cancer cells by blocking the cycle in S phase [119]. Ellagic acid induces cell cycle arrest at G0-G1 in human breast cancer MCF-7 cells mediated by a cyclin A2 and cyclin E2 downregulation and an upregulation of the CDK-inhibitors $p 21^{\text {Cip1 }}, p 15$ and $p 19$ [120].

In addition to cytostatic activity, however, uncontrolled proliferation can be also treated through cytotoxic mechanisms like apoptosis, autophagy, necrosis or necroptosis. Polyphenols can participate in all these mechanisms as described below.

\subsubsection{Apoptosis}

Apoptosis is the main mechanism of cell-programmed death. It is characterized by a series of molecular processes that result in cell membrane blebbing, nuclear and chromosomal DNA fragmentation, chromatin condensation, fragmentation and the translocation of phosphatidylserine to the outer face of the plasma membrane, which means that they are eliminated by macrophages [121-123].

There are two different apoptotic pathways, mainly differentiated by their starting stimuli. These two pathways may overlap and share some molecular targets as caspases [121]. On the one hand, the extrinsic pathway is mediated by ligands that bind to receptors on the cell surface. Alternatively, the intrinsic pathway is mediated by cellular stress or by DNA injury. There are several molecular mechanisms that tumor cells use to suppress apoptosis. For example, tumor cells may acquire resistance to apoptosis by downregulation of anti-apoptotic Bcl-2 expression or mutation of the pro-apoptotic BAX protein. Expression of both is regulated by the tumor suppressor gene p53 [124], which is mutated in a large number of cancer types [125]. 
As occurred in previous sections, polyphenols can act over different stages of apoptosis. For example, anti-apoptotic Bcl-2 expression is decreased in human breast cancer cell lines, MCF-7 and T47D with a silibinin treatment [126]. Besides, silibinin upregulated phosphatidylinositol-3,4,5trisphosphate-3-phosphatase (PTEN) and caused a slight increase in p21, thus promoting apoptosis [127,128]. The treatment with Annurca apple polyphenolic extract increases the levels of p53, p21 and the pro-apoptotic ratio of Bax/Bcl-2 in parallel with caspase- $9,-6$ and -7 , in MCF-7 breast cancer cells [129]. Fruit peel polyphenolic extract from different sources (red grape, blackberry, black cherry, black currant, elderberry, blackthorn and plum) induced caspase-dependent cell death associated with an increase in oxidative stress, causing the release of pro- and anti-apoptotic mitochondrial proteins from the Bcl-2 family in breast cancer MCF-7 cells [130]. Oleuropein induced apoptosis due to upregulation of both p53 and Bax gene expression levels and downregulation of $\mathrm{Bcl} 2$ in human breast cancer MCF-7 cells [131] and in the HepG2 human hepatoma cell line [132].

Tea polyphenols such as epigallocatechin gallate (EGCG) downregulate telomerase activity in breast cancer cells thereby increasing cellular apoptosis and inhibiting cellular proliferation of MCF-7 and MDA-MB-231 breast cancer cells [133]. They can also inhibit cell growth and induce apoptosis through downregulation of survivin expression, a member of the inhibitor apoptosis protein family (IAP) that inhibits caspases and blocks cell death [134]; this effect has been observed in MCF-7, SK-BR-3 cells and MDA-MB-231 breast cancer cell models $[135,136]$.

Artichoke polyphenols modify Bcl-2 and BAX expression in human breast cancer cell line MDA-MB-231, leading to a pro-apoptotic situation [137], which was accompanied with the upregulation of p21 [138].

Finally, other widely-distributed polyphenols such as resveratrol [139], quercetin [140] and catechin [141], promote apoptosis by decreasing IAP1 and survivin expression and increasing FAS ligand and its receptor [142] expression.

\subsubsection{Autophagy}

Initially, autophagy or cellular autodigestion is a route involved in the degradation of proteins and organelles that may be important in the pathogenesis of some diseases. Dysfunctions in the autophagy process are associated with cancer [143-145], neurodegeneration [146,147], aging [147,148] and infections $[149,150]$. The major proteins involved in the regulation of autophagy are the mammalian target of the rapamycin (mTOR), phosphatidylinositol 3 kinase (PI3K), AKT kinase (AKT), Beclin-1 and p53 [151]. Activation of the PI3K/AKT pathway implies mTOR activation, leading to autophagy inhibition [152]; on the contrary, mTOR inhibition is related to autophagy activation. In addition to mTOR, there is a family of proteins called ATG (autophagy-related protein), such as LC3, ATG5 or ATG12, that are also involved in the regulation of this mechanism.

Some polyphenols can induce tumor cell death through autophagy activation; for example, Solanum nigrum L. extract decreased p-AKT levels causing mTOR inactivation and triggering autophagy in AU565 human breast cancer cells [153], as well as blueberry polyphenols in MDA-MB231 cells [154] and grape skin extracts in a murine model of breast cancer [155]. Mango polyphenols cause downregulation of mTOR in human breast ductal carcinoma in situ xenograft models [156].

Resveratrol increases levels of LC3 and its lipidic form, LC3-II, which induces autophagy [157] in human breast cancer MCF-7 cells [158], as well as polyphenol-enriched extract of Pimenta dioica berries does in human breast cancer MCF-7, MDA-MB231, SkBr3, BT474 and T47D cells [159] and carnosol in MDA-M231 cells [160]. In another study, it was observed that LC3-II, Beclin 1 and Atg 7 were significantly upregulated by resveratrol [161], inducing autophagy.

\subsection{Chronic Inflammation and Pro-Inflammatory Factors}

Chronic inflammation has been linked to the development of some tumors [162-164], and it is known that diseases such as pancreatitis [165], hepatic steatosis or Crohn's disease [166], which present chronic inflammation, significantly increase the risk of cancer. This direct relationship with 
cancer development is also observed in infectious diseases that produce inflammation, such as hepatitis [167,168] or stomach infection by Helicobacter pylori [169-171].

Cell signaling by inflammatory cytokines had been shown to promote the development of cancer [172,173]. However, it was not until 2008, when the direct link between inflammation and cancer was first established, when it was observed that chronic inflammation causing DNA damage led to cancer development [174].

The abilities to inhibit or block the activity of NF-kB [175,176], cyclooxygenase (COX-2) [176-178] and lipoxygenase (LOX) $[178,179]$ are the main causes of the anti-inflammatory capacity observed for polyphenols; thus, the role of phytochemicals in these pathways and in cancer-related inflammation has been extensively studied [180]. In this regard, individual polyphenols such as curcumin, EGCG and resveratrol have been reported to show anti-inflammatory effects [180], most of them by reducing NF- $\mathrm{kB}$ activation or expression. In addition to individual compounds, cocoa polyphenols decreased the nuclear levels of NF- $\mathrm{kB}$ and the expression of pro-inflammatory enzymes such as COX-2 and inducible NO synthase. Additionally, cocoa polyphenols effectively downregulated the levels of inflammatory markers induced by tumor necrosis factor-alpha (TNF- $\alpha$ ) by inhibiting NF-KB translocation and JNK phosphorylation [181].

Pomegranate polyphenols also demonstrated anti-inflammatory activity as they were able to decrease NF- $\mathrm{KB}$ [182] and Nrf-2 [183] pathways in breast cancer cells. Cranberry extract also showed the ability to modulate PI3K/AKT, MAPK/ERK and STAT3 pathways, central nodes in the inflammatory signaling of cancer stem cells [184].

\subsection{ER and Estrogen Synthesis}

Estrogens exert their biological action by binding to ER- $\alpha$ and ER- $\beta$, both of which are members of the nuclear receptor superfamily of transcription factors. Although both ERs can develop estrogen-related responses, ER- $\alpha$ is the one that plays an important role in breast cancer (in this review, the term "ER" is used for "ER- $\alpha$ ").

The effects of polyphenols on ER and estrogen pathway is mainly based on three actions: anti-estrogenic mechanisms [185-187], changes in ER expression and aromatase modulation [188-190] (Figure 2). Anti-estrogenic mechanisms are based on the structural similarities between some groups of flavonoids, such as isoflavones and lignans, and estrogens. In fact, these compounds are considered as phytoestrogens [191-197] due to their natural origin and their ability to interact with ERs. Polyphenols may exert different effects according to the dose administered. Low dose treatments have an activating effect on the estrogen receptor, which triggers the proliferative response favoring tumor development. Conversely, high concentrations promote processes such as apoptosis or cell cycle blockage resulting in antitumor effects as mentioned above. In addition, ER expression is also regulated by some polyphenols, for example, EGCG, which downregulates ER- $\alpha$ protein, mRNA and gene promoter activity in MCF-7 [198] and ER and PR in T-47D [199] cell lines. There are so many additional examples of flavonoids, like apigenin, luteolin myricetin, anthocyanidins or quercetin, and other compounds, such as stilbenes, ellagitannins, sulforaphanes, curcuminoids and tocopherols, among others, that are extensively reviewed $[197,200]$.

Aromatase enzyme, a member of the CYP superfamily of enzymes, is encoded by the CYP19 gene and supposed to be another target of breast cancer. Its function is to aromatize androgens, producing estrogens. One strategy to counteract the proliferative effect of estrogen in breast cancer is to use aromatase inhibitors. Some polyphenols have shown aromatase inhibiting properties like biochanin A, an isoflavone extracted from red clover, and genistein, which have been reported to inhibit the activity of the aromatase enzyme in SK-BR3 [201]. Resveratrol also inhibits aromatase by significantly reducing the CYP19-encoding mRNA abundance in SK-BR-3 cells [202]. Isoliquiritigenin inhibited aromatase mRNA expression and suppressed the activity of CYP19 promoters I.3 and II in MCF-7 cells [203]. 


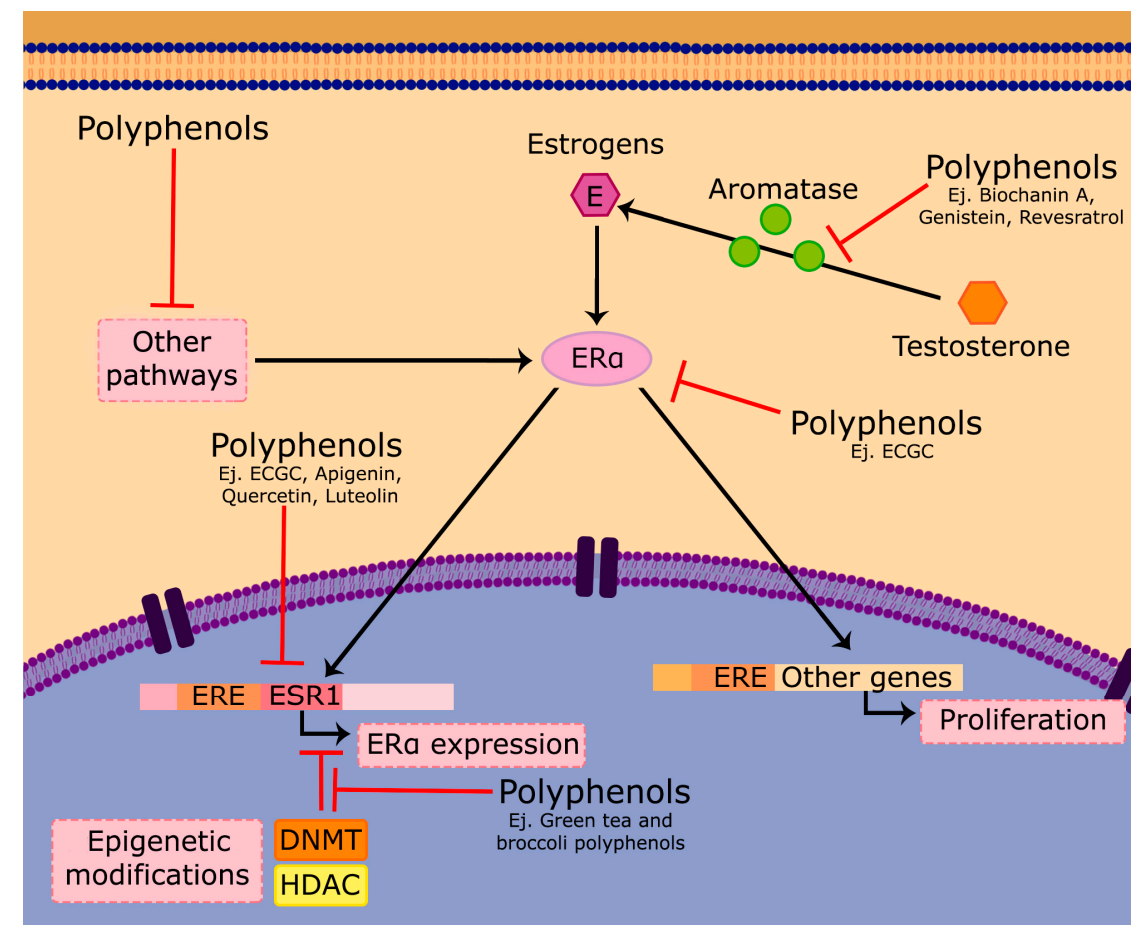

Figure 2. Estrogenic response can be modulated by polyphenol activity. ER activation leads to cell proliferation by activating estrogen response element (ERE)-controlled genes, including their own ER gene (ESR1). Some polyphenols are able both to inhibit ER activity (antiestrogenic action) or ER expression and consequently reduce cell proliferation. The ER activity can also be regulated by some transactivation pathways including the Ras/Raf, PI3K/Akt, AMPK or PKC pathways; all of them can be also modified by polyphenols. ESR1 gene expression can be also regulated by epigenetic modifications through chromatin modifying enzymes such as DNMT (DNA methyltransferases) and HDAC (histone deacetylases). Finally, estrogen synthesis from androgens by aromatase can be also blocked by some polyphenols.

Besides the above-mentioned mechanisms, some polyphenols are able to transform ER-negative phenotypes into ER-positive, thereby improving prognosis and allowing treatment with SERMs such as tamoxifen. This transformation may be due to epigenetic modifications mediated by chromatin modifying enzymes such as DNMT (DNA methyltransferases) and HDAC (histone deacetylases) [204-206]. Methylation of the ESR1 gene encoding for ER is associated with the ER-negative phenotype and therefore supports the hypothesis that treatment with DNMT inhibitors and HDAC activators can promote ER expression by reversing the ER-negative phenotype to ER-positive [207]. Green tea polyphenols have been shown to modify chromatin by inhibiting DNMTs and eliciting ER expression in the TNBC MDA-MB231 cell line [208]. It has also been observed that with a combined treatment of green tea extract and broccoli shoots, the epigenetic reactivation of ER is triggered, which in turn increases the sensitivity to tamoxifen in ER-negative breast cancer MDA-MB-231 and MDA-MB-157 cells.

\subsection{HER2/ErRB Overexpression}

HER2, also termed ERBB2 or EGFR2, is overexpressed in more than $30 \%$ of breast cancers and has been shown to play an important role in the progression of certain aggressive breast cancers. HER2 is a trans-membrane receptor tyrosine kinase that activates multiple proliferative signaling pathways, including PI3K/Akt and Ras/MAPK. Upon activation, HER2 can both homo- or hetero-dimerize with other HER family receptors, leading to signal transduction and cell proliferation (Figure 3). This is the main reason for which HER2 overexpression conduces to an abnormal proliferation and cancer 
spread. In addition to this main mechanism, however, it has also been shown that several apoptotic mechanisms are deregulated in cells overexpressing HER2 [209,210], and some anti-apoptotic proteins including Bcl-2, Bcl-xL and Mcl-1 are overexpressed [211]. These two additional mechanisms contribute to tumor cell survival and the spread of the cancer (Figure 3).

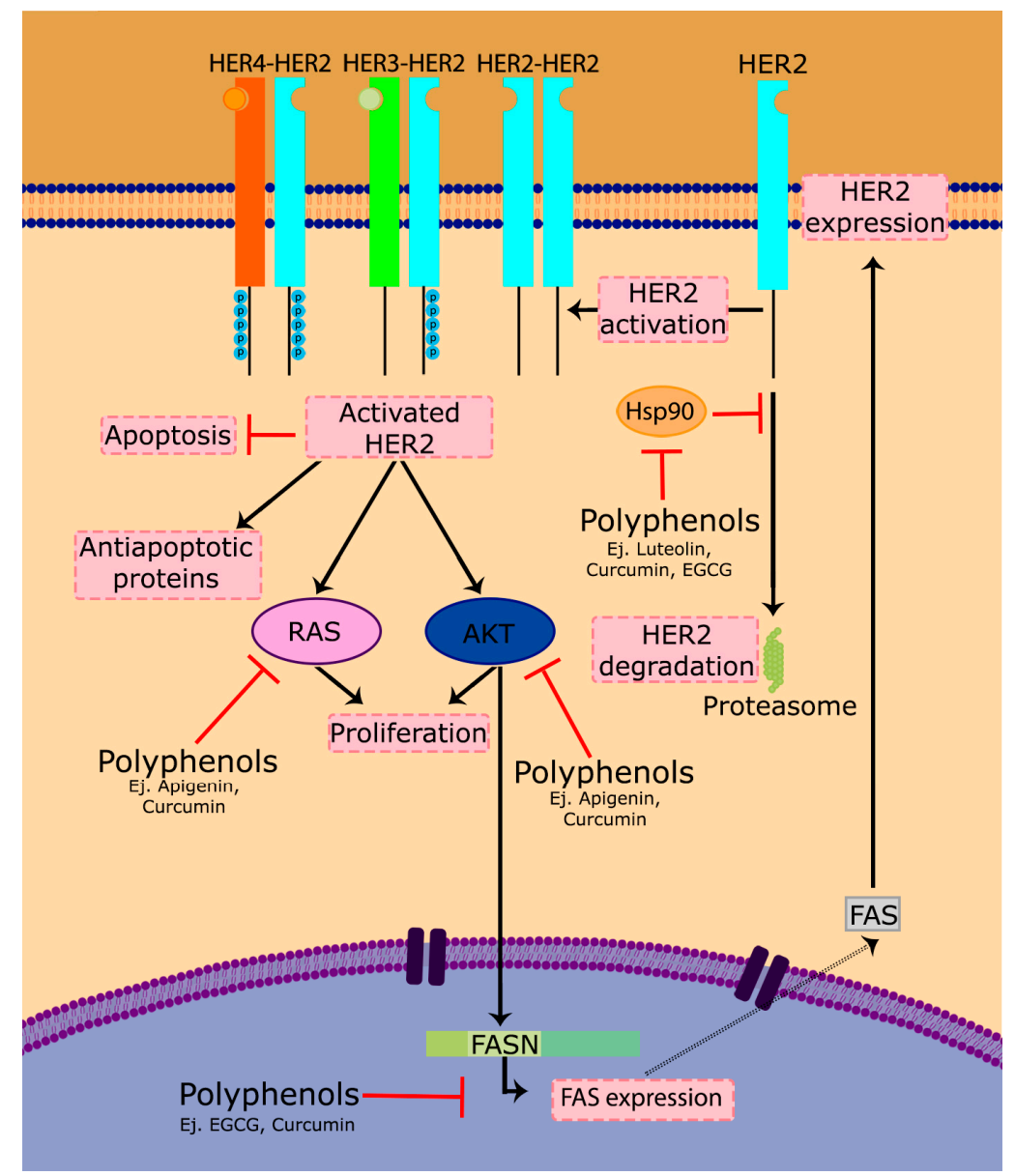

Figure 3. Polyphenols modulate the HER2 pathway. The HER2 membrane receptor, when activated, dimerizes with other HER2 (homodimerization) or other HER family receptor (heterodimerization) and transduces proliferation signals to downstream pathways such as the Ras/Raf or PI3K/Akt routes. This activation also inhibits apoptotic signals and promote antiapoptotic mechanisms. In addition, HER2 expression can be modulated by FASN, and some polyphenols are able to modify this action by actuating on FASN activity and/or expression. Finally, Hsp90 chaperone is required for HER2 to be functional, and some polyphenols modify this interaction leading to HER2 degradation by proteasome.

Nowadays, the most commonly-used therapy against HER2-positive tumors is the monoclonal antibody trastuzumab [212]. This treatment has positively revolutionized the prognosis of this kind of tumor; however, the main problem presented by these patients is the development of resistance to trastuzumab. Polyphenols can sensitize HER2-positive cells through different mechanisms: by decreasing its activation or downloading its expression. For example, some secoiridoids such as oleuropein promote a downregulation of HER2 by blocking ATP binding to the tyrosine kinase domain of the protein $[213,214]$. Silybin and silybin-phosphatidylcholine exhibit dose-dependent cell growth inhibitory effects and downregulation of HER2 in SkBr3 cells [215]. Apigenin induces apoptosis by depletion of HER2 protein and, in turn, suppression of signaling of the HER2/HER3-PI3K/Akt pathway [216]. HER2, p-Akt, p-MAPK and NF-kB oncoprotein levels decreased in a dose- and 
time-dependent way in BT-474, MCF- 7, MDA-MB-231 and SkBr3-hr (a herceptin-resistant strain from $\mathrm{SkBr} 3$ breast cancer cells) when treated with curcumin [217].

On the other hand, HER2 needs to interact with Hsp90 and its chaperone to acquire its function [218,219], so another possible therapeutic approach is the use of inhibitors of the HER2-Hsp90 binding, causing the dissociation of HER2 from its chaperone and, consequently, leading to HER2 degradation by the proteasome [220,221]. It has been observed that some polyphenols such as luteolin [222], geraniin [223], curcumin [224] or EGCG [225] are inhibitors of Hsp90 and therefore affect the HER2-Hsp90 binding.

Fatty acid synthase (FASN) has been linked with several types of cancer [226]. Overexpression of HER2 has been shown to increase FASN translation, which alters the activity of the mTOR and the PI3K/AKT signaling pathway in breast cancer cells [227]. FASN inhibition induces apoptosis and creates cytotoxicity [228-230], but also causes a marked decrease in the active forms of the HER2 protein, indicating that the HER2 oncogene presents positive feedback with FASN to ensure de novo overactive biogenesis of fatty acids. Consequently, FASN inhibition correlates with an inhibition of HER2 (Figure 3). Some polyphenols, such as curcumin [231], some olive oil lignans [232] and EGCG [233] have shown anticancer activity on HER-positive models through this FASN-linked mechanism.

\section{Conclusions}

Breast cancer is a heterogenic oncological disease in which, in addition to common cancer signatures, estrogenic response and HER2 expression constitute two clinical and molecular targets that must be taken into account.

As stated in this review, polyphenols are natural compounds that have demonstrated antitumor activity reaching different molecular targets. Some of them, especially EGCG, curcumin and flavonoids, such as luteolin, apigenin or quercetin, seem to be the most promising ones according to the current studies. Their promiscuous activity against different molecular targets is quite relevant and suggests that multitargeting therapy can be a future strategy for breast cancer treatment. However, additional aspects such as polyphenols' bioavailability and toxicity must be addressed. Polyphenols' bioavailability has been thoroughly studied for many polyphenols, especially those with the most relevant biological activity [234]. In general, polyphenols' bioavailability is low, and most of them are classified as Class IV by the Biopharmaceutical Classification System (BCS) (low permeability, low solubility) [235]. However, numerous studies have explored strategies to increase polyphenols' bioavailability, for example using different encapsulation techniques [236-239] or using pharmaceutical dispersions [240]. Intravenous administration represents an option for many anticancer drugs with poor bioavailability, so this could be a solution too for those polyphenols showing low bioavailability.

Toxicity is, as mentioned above, another relevant aspect to be studied. As occurred with their bioavailability, polyphenols' toxicity has been deeply studied [241-243], and in most cases, only very high doses present relevant toxic consequences. Moreover, new approaches to predict toxicity using bioinformatic tools such as admetSAR and DataWarrior [244,245] are also available, and new alternative methods both reducing and/or replacing animal use have been introduced in preclinical research (see http:/ / www.oecd.org/chemicalsafety/testing/animal-welfare.htm). However, toxicity should not be a major problem since polyphenols are less toxic than most anticancer drugs.

All the accumulated evidence on the in vitro anticancer activity of polyphenols, as well as bioavailability and toxicity studies may be used to develop new anticancer drugs. Nevertheless, much preclinical research needs to be conducted before administration to oncologic patients with the required guaranties. In vivo studies and, especially, human clinical trials must be developed before real clinical use. However, most of these polyphenols can be obtained from the diet, allowing preventive or nutritional strategies that, although they must be challenged with clinical trials before being accepted, can be implemented in the short term as dietary recommendations. Some studies have been already conducted $[48,49]$, but there is still a need for more evidence. 
Future research must be focused on providing new and strong evidence about polyphenols' activity on every breast cancer signature. As mentioned above, preclinical and clinical evidence is scarce. New studies using omic sciences and in silico approaches could provide some of the pending results as occurred in other disciplines. Genomics, transcriptomics, proteomics, metabolomics and fluxomics strategies are continuously increasing our knowledge about polyphenols' mechanism of action [246,247]. In silico techniques, such as molecular docking, are being used to identify new ligands for specific cancer molecular targets [248,249]. Epigenetic studies are also providing relevant information $[250,251]$ on polyphenols' effects, but a global approach using all the updated knowledge is undoubtedly the main pending task.

Acknowledgments: Some of the investigations expressed in this review have been partially or fully supported by competitive public grants from the following institutions: AGL2011-29857-C03-03 and IDI-20120751 grants (Spanish Ministry of Science and Innovation), Projects AGL2015-67995-C3-1-R, AGL2015-67995-C3-2-R, AGL2015-67995-C3-3-Rfrom the Spanish Ministry of Economy and Competitiveness (MINECO); PROMETEO/2012/007, PROMETEO/2016/006, ACOMP/2013/093, ACIF/2010/162 and ACIF/2016/230 grants from Generalitat Valenciana and CIBER (CB12/03/30038, Fisiopatologia de la Obesidad y la Nutricion, CIBERobn, Instituto de Salud Carlos III).

Author Contributions: María Losada-Echeberría gathered all the information and wrote the first version of the manuscript. María Herranz-López reviewed and added new information about polyphenols to the manuscript. Vicente Micol reviewed the manuscript and the English language. Enrique Barrajón-Catalán coordinated all the authors and edited and reviewed the different versions of the manuscript.

Conflicts of Interest: The authors declare no conflict of interest.

\section{Abbreviations}

$\begin{array}{ll}\text { HER2/ERB2 } & \text { human epidermal growth factor receptor } 2 \\ \text { CYP } & \text { cytochrome P450s } \\ \text { GST } & \text { s-transferase } \\ \text { TNBC } & \text { triple negative breast cancer } \\ \text { ER } & \text { estrogen receptor } \\ \text { PR } & \text { progesterone receptor } \\ \text { ROS } & \text { reactive oxygen species } \\ \text { SOD } & \text { superoxide dismutase } \\ \text { CAT } & \text { catalase } \\ \text { GTX } & \text { glutathione peroxidase } \\ \text { CDKs } & \text { cyclin-dependent kinases } \\ \text { APC/C } & \text { anaphase-promoting complex } \\ \text { PTEN } & \text { phosphatidylinositolo-3,4,5-trisphosphate-3-phosphatase } \\ \text { EGCG } & \text { epigallocatechin gallate } \\ \text { IAP } & \text { inhibitor apoptosis protein } \\ \text { mTOR } & \text { mammalian target of the rapamycin } \\ \text { PI3K } & \text { phosphatidylinositol 3 kinase } \\ \text { AKT } & \text { AKT kinase } \\ \text { COX-2 } & \text { cyclooxygenase } \\ \text { LOX } & \text { lipoxygenase } \\ \text { TNF- } \alpha & \text { Tumoral Necrosis Factor-alpha } \\ \text { DNMTs } & \text { DNA methyltransferases } \\ \text { HDACs } & \text { histone deacetylases } \\ \text { FASN } & \text { fatty acid synthase } \\ & \end{array}$

\section{References}

1. Ferlay, J.; Soerjomataram, I.; Dikshit, R.; Eser, S.; Mathers, C.; Rebelo, M.; Parkin, D.M.; Forman, D.; Bray, F. Cancer incidence and mortality worldwide: Sources, methods and major patterns in globocan 2012. Int. J. Cancer 2015, 136, E359-E386. [CrossRef] [PubMed] 
2. Torre, L.A.; Bray, F.; Siegel, R.L.; Ferlay, J.; Lortet-Tieulent, J.; Jemal, A. Global cancer statistics, 2012. CA Cancer J. Clin. 2015, 65, 87-108. [CrossRef] [PubMed]

3. Balduzzi, S.; Mantarro, S.; Guarneri, V.; Tagliabue, L.; Pistotti, V.; Moja, L.; D’Amico, R. Trastuzumabcontaining regimens for metastatic breast cancer. Cochrane Database Syst. Rev. 2014, 12, CD006242.

4. Li, X.X.; Oprea-Ilies, G.M.; Krishnamurti, U. New developments in breast cancer and their impact on daily practice in pathology. Arch. Pathol. Lab. Med. 2017, 141, 490-498. [CrossRef] [PubMed]

5. Singh, S.; Sharma, B.; Kanwar, S.S.; Kumar, A. Lead phytochemicals for anticancer drug development. Front. Plant Sci. 2016, 7, 1667. [CrossRef] [PubMed]

6. Kawada, M.; Atsumi, S.; Wada, S.I.; Sakamoto, S. Novel approaches for identification of anti-tumor drugs and new bioactive compounds. J. Antibiot. 2017. [CrossRef] [PubMed]

7. Ruiz-Torres, V.; Encinar, J.; Herranz-López, M.; Pérez-Sánchez, A.; Galiano, V.; Barrajón-Catalán, E.; Micol, V. An updated review on marine anticancer compounds: The use of virtual screening for the discovery of small-molecule cancer drugs. Molecules 2017, 22, 1037. [CrossRef] [PubMed]

8. Garcia-Villalba, R.; Carrasco-Pancorbo, A.; Oliveras-Ferraros, C.; Vazquez-Martin, A.; Menendez, J.A.; Segura-Carretero, A.; Fernandez-Gutierrez, A. Characterization and quantification of phenolic compounds of extra-virgin olive oils with anticancer properties by a rapid and resolutive LC-ESI-TOF MS method. J. Pharm. Biomed. Anal. 2010, 51, 416-429. [CrossRef] [PubMed]

9. Kunnumakkara, A.B.; Bordoloi, D.; Harsha, C.; Banik, K.; Gupta, S.C.; Aggarwal, B.B. Curcumin mediates anticancer effects by modulating multiple cell signaling pathways. Clin. Sci. 2017, 131, 1781-1799. [CrossRef] [PubMed]

10. Bae, J.; Kumazoe, M.; Yamashita, S.; Tachibana, H. Hydrogen sulphide donors selectively potentiate a green tea polyphenol EGCG-induced apoptosis of multiple myeloma cells. Sci. Rep. 2017, 7. [CrossRef] [PubMed]

11. Jahanafrooz, Z.; Motamed, N.; Bakhshandeh, B. Effects of miR-21 downregulation and silibinin treatment in breast cancer cell lines. Cytotechnology 2017, 69, 667-680. [CrossRef] [PubMed]

12. Tyszka-Czochara, M.; Bukowska-Strakova, K.; Majka, M. Metformin and caffeic acid regulate metabolic reprogramming in human cervical carcinoma SiHa/HTB-35 cells and augment anticancer activity of Cisplatin via cell cycle regulation. Food Chem. Toxicol. 2017, 106, 260-272. [CrossRef] [PubMed]

13. Zenthoefer, M.; Geisen, U.; Hofmann-Peiker, K.; Fuhrmann, M.; Kerber, J.; Kirchhofer, R.; Hennig, S.; Peipp, M.; Geyer, R.; Piker, L.; et al. Isolation of polyphenols with anticancer activity from the baltic sea brown seaweed fucus vesiculosus using bioassay-guided fractionation. J. Appl. Phycol. 2017, 29, 2021-2037. [CrossRef]

14. Pereira, T.M.C.; Pimenta, F.S.; Porto, M.L.; Baldo, M.P.; Campagnaro, B.P.; Gava, A.L.; Meyrelles, S.S.; Vasquez, E.C. Coadjuvants in the diabetic complications: Nutraceuticals and drugs with pleiotropic effects. Int. J. Mol. Sci. 2016, 17, 1273. [CrossRef] [PubMed]

15. Gothai, S.; Ganesan, P.; Park, S.Y.; Fakurazi, S.; Choi, D.K.; Arulselvan, P. Natural phyto-bioactive compounds for the treatment of type 2 diabetes: Inflammation as a target. Nutrients 2016, 8, 461. [CrossRef] [PubMed]

16. Abiodun, O.O.; Rodriguez-Nogales, A.; Algieri, F.; Gomez-Caravaca, A.M.; Segura-Carretero, A.; Utrilla, M.P.; Rodriguez-Cabezas, M.E.; Galvez, J. Antiinflammatory and immunomodulatory activity of an ethanolic extract from the stem bark of Terminalia catappa L. (Combretaceae): In vitro and in vivo evidences. J. Ethnopharmacol. 2016, 192, 309-319. [CrossRef] [PubMed]

17. Choi, J.Y.; Desta, K.T.; Saralamma, V.V.G.; Lee, S.J.; Lee, S.J.; Kim, S.M.; Paramanantham, A.; Lee, H.J.; Kim, Y.-H.; Shin, H.-C.; et al. LC-MS/Ms characterization, anti-inflammatory effects and antioxidant activities of polyphenols from different tissues of Korean Petasites japonicus (Meowi). Biomed. Chromatogr. 2017. [CrossRef] [PubMed]

18. Liu, K.; Pi, F.; Zhang, H.; Ji, J.; Xia, S.; Cui, F.; Sun, J.; Sun, X. Metabolomics analysis to evaluate the anti-inflammatory effects of polyphenols: Glabridin reversed metabolism change caused by LPS in RAW 264.7 cells. J. Agric. Food Chem. 2017, 65, 6070-6079. [CrossRef] [PubMed]

19. Nakajima, V.M.; Moala, T.; Caria, C.R.E.P.; Moura, C.S.; Amaya-Farfan, J.; Gambero, A.; Macedo, G.A.; Macedo, J.A. Biotransformed citrus extract as a source of anti-inflammatory polyphenols: Effects in macrophages and adipocytes. Food Res. Int. 2017, 97, 37-44. [CrossRef] [PubMed]

20. Herranz-López, M.; Olivares-Vicente, M.; Encinar, J.A.; Barrajón-Catalán, E.; Segura-Carretero, A.; Joven, J.; Micol, V. Multi-targeted molecular effects of Hibiscus sabdariffa polyphenols: An opportunity for a global approach to obesity. Nutrients 2017, 9, 907. [CrossRef] [PubMed] 
21. Molino, S.; Dossena, M.; Buonocore, D.; Ferrari, F.; Venturini, L.; Ricevuti, G.; Verri, M. Polyphenols in dementia: From molecular basis to clinical trials. Life Sci. 2016, 161, 69-77. [CrossRef] [PubMed]

22. Isac, S.; Panaitescu, A.M.; Spataru, A.; Iesanu, M.; Totan, A.; Udriste, A.; Cucu, N.; Peltecu, G.; Zagrean, L.; Zagrean, A.M. Trans-resveratrol enriched maternal diet protects the immature hippocampus from perinatal asphyxia in rats. Neurosci. Lett. 2017, 653, 308-313. [CrossRef] [PubMed]

23. Reglodi, D.; Renaud, J.; Tamas, A.; Tizabi, Y.; Socias, S.B.; Del-Bel, E.; Raisman-Vozari, R. Novel tactics for neuroprotection in parkinson's disease: Role of antibiotics, polyphenols and neuropeptides. Prog. Neurobiol. 2017, 155, 120-148. [CrossRef] [PubMed]

24. De Camargo, A.C.; Regitano-d'Arce, M.A.B.; Rasera, G.B.; Canniatti-Brazaca, S.G.; do Prado-Silva, L.; Alvarenga, V.O.; Sant'Ana, A.S.; Shahidi, F. Phenolic acids and flavonoids of peanut by-products: Antioxidant capacity and antimicrobial effects. Food Chem. 2017, 237, 538-544. [CrossRef] [PubMed]

25. Paunovic, S.M.; Maskovic, P.; Nikolic, M.; Miletic, R. Bioactive compounds and antimicrobial activity of black currant (Ribes nigrum L.) berries and leaves extract obtained by different soil management system. Sci. Hortic. 2017, 222, 69-75. [CrossRef]

26. Chen, M.S.; Zhao, Z.G.; Meng, H.C.; Yu, S.J. Antibiotic activity and mechanisms of sugar beet (beta vulgaris) molasses polyphenols against selected food-borne pathogens. LWT Food Sci. Technol. 2017, 82, 354-360. [CrossRef]

27. Gomez-Estaca, J.; Balaguer, M.P.; Lopez-Carballo, G.; Gavara, R.; Hernandez-Munoz, P. Improving antioxidant and antimicrobial properties of curcumin by means of encapsulation in gelatin through electrohydrodynamic atomization. Food Hydrocoll. 2017, 70, 313-320. [CrossRef]

28. Sanchez-Roque, Y.; Ayora-Talavera, G.; Rincon-Rosales, R.; Gutierrez-Miceli, F.A.; Meza-Gordillo, R.; Winkler, R.; Gamboa-Becerra, R.; Ayora-Talavera, T.D.; Ruiz-Valdiviezo, V.M. The flavonoid fraction from rhoeo discolor leaves acting as antiviral against influenza a virus. Rec. Nat. Prod. 2017, 11, 532-546. [CrossRef]

29. Vazquez-Calvo, A.; de Oya, N.J.; Martin-Acebes, M.A.; Garcia-Moruno, E.; Saiz, J.C. Antiviral properties of the natural polyphenols delphinidin and epigallocatechin gallate against the flaviviruses west nile virus, zika virus, and dengue virus. Front. Microbiol. 2017, 8, 1314. [CrossRef] [PubMed]

30. Scalbert, A.; Johnson, I.T.; Saltmarsh, M. Polyphenols: Antioxidants and beyond. Am. J. Clin. Nutr. 2005, 81, 215S-217S. [PubMed]

31. Lindsay, D.G.; Astley, S.B. European research on the functional effects of dietary antioxidants-EUROFEDA. Mol. Asp. Med. 2002, 23, 1-38. [CrossRef]

32. Bhattarai, G.; Poudel, S.B.; Kook, S.H.; Lee, J.C. Anti-inflammatory, anti-osteoclastic, and antioxidant activities of genistein protect against alveolar bone loss and periodontal tissue degradation in a mouse model of periodontitis. J. Biomed. Mater. Res. Part A 2017, 105, 2510-2521. [CrossRef] [PubMed]

33. Dehkharghanian, M.; Lacroix, M.; Vijayalakshmi, M.A. Antioxidant properties of green tea polyphenols encapsulated in caseinate beads. Dairy Sci. Technol. 2009, 89, 485-499. [CrossRef]

34. Dairi, S.; Carbonneau, M.A.; Galeano-Diaz, T.; Remini, H.; Dahmoune, F.; Aoun, O.; Belbahi, A.; Lauret, C.; Cristol, J.P.; Madani, K. Antioxidant effects of extra virgin olive oil enriched by myrtle phenolic extracts on iron-mediated lipid peroxidation under intestinal conditions model. Food Chem. 2017, 237, 297-304. [CrossRef] [PubMed]

35. Ursache, F.M.; Ghinea, I.O.; Turturica, M.; Aprodu, I.; Rapeanu, G.; Stanciuc, N. Phytochemicals content and antioxidant properties of sea buckthorn (Hippophae rhamnoides L.) as affected by heat treatment-Quantitative spectroscopic and kinetic approaches. Food Chem. 2017, 233, 442-449. [CrossRef] [PubMed]

36. Lambert, J.D.; Hong, J.; Yang, G.Y.; Liao, J.; Yang, C.S. Inhibition of carcinogenesis by polyphenols: Evidence from laboratory investigations. Am. J. Clin. Nutr. 2005, 81, 284S-291S. [PubMed]

37. Duluc, L.; Jacques, C.; Soleti, R.; Iacobazzi, F.; Simard, G.; Andriantsitohaina, R. Modulation of mitochondrial capacity and angiogenesis by red wine polyphenols via estrogen receptor, NADPH oxidase and nitric oxide synthase pathways. Int. J. Biochem. Cell Biol. 2013, 45, 783-791. [CrossRef] [PubMed]

38. Khan, N.; Mukhtar, H. Modulation of signaling pathways in prostate cancer by green tea polyphenols. Biochem. Pharmacol. 2013, 85, 667-672. [CrossRef] [PubMed]

39. Nunes, C.; Teixeira, N.; Serra, D.; Freitas, V.; Almeida, L.; Laranjinha, J. Red wine polyphenol extract efficiently protects intestinal epithelial cells from inflammation via opposite modulation of JAK/STAT and Nrf2 pathways. Toxicol. Res. 2016, 5, 53-65. [CrossRef] 
40. Scapagnini, G.; Vasto, S.; Abraham, N.G.; Caruso, C.; Zella, D.; Galvano, F. Modulation of Nrf2/ARE pathway by food polyphenols: A nutritional neuroprotective strategy for cognitive and neurodegenerative disorders. Mol. Neurobiol. 2011, 44, 192-201. [CrossRef] [PubMed]

41. Joven, J.; Micol, V.; Segura-Carretero, A.; Alonso-Villaverde, C.; Menendez, J.A. Bioactive Food Components Platform. Polyphenols and the modulation of gene expression pathways: Can we eat our way out of the danger of chronic disease? Crit. Rev. Food Sci. Nutr. 2014, 54, 985-1001. [CrossRef] [PubMed]

42. Jayasena, T.; Poljak, A.; Smythe, G.; Braidy, N.; Muench, G.; Sachdev, P. The role of polyphenols in the modulation of sirtuins and other pathways involved in Aalzheimer's disease. Ageing Res. Rev. 2013, 12, 867-883. [CrossRef] [PubMed]

43. Sloczynska, K.; Powroznik, B.; Pekala, E.; Waszkielewicz, A.M. Antimutagenic compounds and their possible mechanisms of action. J. Appl. Genet. 2014, 55, 273-285. [CrossRef] [PubMed]

44. Rodeiro, I.; Donato, M.T.; Jimenez, N.; Garrido, G.; Molina-Torres, J.; Menendez, R.; Castell, J.V.; Gomez-Lechon, M.J. Inhibition of human P450 enzymes by natural extracts used in traditional medicine. Phytother. Res. 2009, 23, 279-282. [CrossRef] [PubMed]

45. Munday, R.; Munday, C.M. Induction of phase II detoxification enzymes in rats by plant-derived isothlocyanates: Comparison of allyl isothiocyanate with sulforaphane and related compounds. J. Agric. Food Chem. 2004, 52, 1867-1871. [CrossRef] [PubMed]

46. Lu, F.; Zahid, M.; Wang, C.; Saeed, M.; Cavalieri, E.L.; Rogan, E.G. Resveratrol prevents estrogen-DNA adduct formation and neoplastic transformation in MCF-10F cells. Cancer Prev. Res. 2008, 1, $135-145$. [CrossRef] [PubMed]

47. Pérez-Sánchez, A.; Barrajón-Catalán, E.; Herranz-López, M.; Castillo, J.; Micol, V. Lemon balm extract (Melissa officinalis L.) promotes melanogenesis and prevents UVB-induced oxidative stress and DNA damage in a skin cell model. J. Dermatol. Sci. 2016, 84, 169-177. [CrossRef] [PubMed]

48. Grosso, G.; Godos, J.; Lamuela-Raventos, R.; Ray, S.; Micek, A.; Pajak, A.; Sciacca, S.; D'Orazio, N.; Del Rio, D.; Galvano, F. A comprehensive meta-analysis on dietary flavonoid and lignan intake and cancer risk: Level of evidence and limitations. Mol. Nutr. Food Res. 2017, 61. [CrossRef] [PubMed]

49. Grosso, G.; Micek, A.; Godos, J.; Pajak, A.; Sciacca, S.; Galvano, F.; Giovannucci, E.L. Dietary flavonoid and lignan intake and mortality in prospective cohort studies: Systematic review and dose-response meta-analysis. Am. J. Epidemiol. 2017, 185, 1304-1316. [CrossRef] [PubMed]

50. Kale, A.; Gawande, S.; Kotwal, S.; Netke, S.; Roomi, M.W.; Ivanov, V.; Niedzwecki, A.; Rath, M. A combination of green tea extract, specific nutrient mixture and quercetin: An effective intervention treatment for the regression of $N$-methyl-N-nitrosourea (MNU)-induced mammary tumors in Wistar rats. Oncol. Lett. 2010, 1, 313-317. [PubMed]

51. Venkatesan, T.; Choi, Y.W.; Mun, S.P.; Kim, Y.K. Pinus radiata bark extract induces caspase-independent apoptosis-like cell death in MCF-7 human breast cancer cells. Cell Biol. Toxicol. 2016, 32, 451-464. [CrossRef] [PubMed]

52. Chang, C.H.; Ou, T.T.; Yang, M.Y.; Huang, C.C.; Wang, C.J. Nelumbo nucifera gaertn leaves extract inhibits the angiogenesis and metastasis of breast cancer cells by downregulation connective tissue growth factor (CTGF) mediated PI3K/AKT/ERK signaling. J. Ethnopharmacol. 2016, 188, 111-122. [CrossRef] [PubMed]

53. Studzinska-Sroka, E.; Piotrowska, H.; Kucinska, M.; Murias, M.; Bylka, W. Cytotoxic activity of physodic acid and acetone extract from hypogymnia physodes against breast cancer cell lines. Pharm. Biol. 2016, 54, 2480-2485. [CrossRef] [PubMed]

54. Sharma, K.; Pachauri, S.D.; Khandelwal, K.; Ahmad, H.; Arya, A.; Biala, P.; Agrawal, S.; Pandey, R.R.; Srivastava, A.; Srivastav, A.; et al. Anticancer effects of extracts from the fruit of morinda citrifolia (noni) in breast cancer cell lines. Drug Res. 2016, 66, 141-147. [CrossRef] [PubMed]

55. Bouallagui, Z.; Han, J.; Isoda, H.; Sayadi, S. Hydroxytyrosol rich extract from olive leaves modulates cell cycle progression in MCF-7 human breast cancer cells. Food Chem. Toxicol. 2011, 49, 179-184. [CrossRef] [PubMed]

56. Fogli, S.; Arena, C.; Carpi, S.; Polini, B.; Bertini, S.; Digiacomo, M.; Gado, F.; Saba, A.; Saccomanni, G.; Breschi, M.C.; et al. Cytotoxic activity of oleocanthal isolated from virgin olive oil on human melanoma cells. Nutr. Cancer Int. J. 2016, 68, 873-877. [CrossRef] [PubMed] 
57. Goldsmith, C.D.; Vuong, Q.V.; Sadeqzadeh, E.; Stathopoulos, C.E.; Roach, P.D.; Scarlett, C.J. Phytochemical properties and anti-proliferative activity of Olea europaea L. Leaf extracts against pancreatic cancer cells. Molecules 2015, 20, 12992-13004. [CrossRef] [PubMed]

58. Barrajon-Catalan, E.; Taamalli, A.; Quirantes-Pine, R.; Roldan-Segura, C.; Arraez-Roman, D.; Segura-Carretero, A.; Micol, V.; Zarrouk, M. Differential metabolomic analysis of the potential antiproliferative mechanism of olive leaf extract on the JIMT-1 breast cancer cell line. J. Pharm. Biomed. Anal. 2015, 105, 156-162. [CrossRef] [PubMed]

59. Dai, X.F.; Li, T.; Bai, Z.H.; Yang, Y.K.; Liu, X.X.; Zhan, J.L.; Shi, B.Z. Breast cancer intrinsic subtype classification, clinical use and future trends. Am. J. Cancer Res. 2015, 5, 2929-2943. [PubMed]

60. Rakha, E.A.; Reis, J.S.; Ellis, I.O. Combinatorial biomarker expression in breast cancer. Breast Cancer Res. Treat. 2010, 120, 293-308. [CrossRef] [PubMed]

61. Sotiriou, C.; Pusztai, L. Molecular origins of cancer gene-expression signatures in breast cancer. N. Engl. J. Med. 2009, 360, 790-800. [CrossRef] [PubMed]

62. Alluri, P.G.; Speers, C.; Chinnaiyan, A.M. Estrogen receptor mutations and their role in breast cancer progression. Breast Cancer Res. 2014, 16. [CrossRef] [PubMed]

63. Mc Cormack, O.; Harrison, M.; Kerin, M.J.; McCann, A. Role of the progesterone receptor (PR) and the PR isoforms in breast cancer. Crit. Rev. Oncog. 2007, 13, 283-301. [CrossRef] [PubMed]

64. Mitri, Z.; Constantine, T.; O'Regan, R. The HER2 receptor in breast cancer: Pathophysiology, clinical use, and new advances in therapy. Chemother. Res. Pract. 2012, 2012, 743193. [CrossRef] [PubMed]

65. Luporsi, E.; André, F.; Spyratos, F.; Martin, P.-M.; Jacquemier, J.; Penault-Llorca, F.; Tubiana-Mathieu, N.; Sigal-Zafrani, B.; Arnould, L.; Gompel, A.; et al. Ki-67: Level of evidence and methodological considerations for its role in the clinical management of breast cancer: Analytical and critical review. Breast Cancer Res. Treat. 2012, 132, 895-915. [CrossRef] [PubMed]

66. Oakman, C.; Bessi, S.; Zafarana, E.; Galardi, F.; Biganzoli, L.; Di Leo, A. Recent advances in systemic therapy. New diagnostics and biological predictors of outcome in early breast cancer. Breast Cancer Res. 2009, 11, 205. [CrossRef] [PubMed]

67. Brenton, J.D.; Carey, L.A.; Ahmed, A.A.; Caldas, C. Molecular classification and molecular forecasting of breast cancer: Ready for clinical application? J. Clin. Oncol. 2005, 23, 7350-7360. [CrossRef] [PubMed]

68. Parker, J.S.; Mullins, M.; Cheang, M.C.U.; Leung, S.; Voduc, D.; Vickery, T.; Davies, S.; Fauron, C.; He, X.P.; $\mathrm{Hu}, \mathrm{Z}$.Y.; et al. Supervised risk predictor of breast cancer based on intrinsic subtypes. J. Clin. Oncol. 2009, 27, 1160-1167. [CrossRef] [PubMed]

69. Lal, S.; McCart Reed, A.E.; de Luca, X.M.; Simpson, P.T. Molecular signatures in breast cancer. Methods 2017. [CrossRef] [PubMed]

70. Fan, C.; Oh, D.S.; Wessels, L.; Weigelt, B.; Nuyten, D.S.A.; Nobel, A.B.; van't Veer, L.J.; Perou, C.M. Concordance among gene-expression-based predictors for breast cancer. N. Engl. J. Med. 2006, 355, 560-569. [CrossRef] [PubMed]

71. Voduc, K.D.; Cheang, M.C.U.; Tyldesley, S.; Gelmon, K.; Nielsen, T.O.; Kennecke, H. Breast cancer subtypes and the risk of local and regional relapse. J. Clin. Oncol. 2010, 28, 1684-1691. [CrossRef] [PubMed]

72. Howlader, N.; Altekruse, S.F.; Li, C.I.; Chen, V.W.; Clarke, C.A.; Ries, L.A.G.; Cronin, K.A. US incidence of breast cancer subtypes defined by joint hormone receptor and HER2 status. JNCI J. Natl. Cancer Inst. 2014, 106. [CrossRef] [PubMed]

73. Arvold, N.D.; Taghian, A.G.; Niemierko, A.; Raad, R.F.A.; Sreedhara, M.; Nguyen, P.L.; Bellon, J.R.; Wong, J.S.; Smith, B.L.; Harris, J.R. Age, breast cancer subtype approximation, and local recurrence after breast-conserving therapy. J. Clin. Oncol. 2011, 29, 3885-3891. [CrossRef] [PubMed]

74. Haque, R.; Ahmed, S.A.; Inzhakova, G.; Shi, J.X.; Avila, C.; Polikoff, J.; Bernstein, L.; Enger, S.M.; Press, M.F. Impact of breast cancer subtypes and treatment on survival: An analysis spanning two decades. Cancer Epidemiol. Biomark. Prev. 2012, 21, 1848-1855. [CrossRef] [PubMed]

75. Metzger, O.; Sun, Z.X.; Viale, G.; Price, K.N.; Crivellari, D.; Snyder, R.D.; Gelber, R.D.; Castiglione-Gertsch, M.; Coates, A.S.; Goldhirsch, A.; et al. Patterns of recurrence and outcome according to breast cancer subtypes in lymph node-negative disease: Results from international breast cancer study group trials VIII and IX. J. Clin. Oncol. 2013, 31, 3083-3090. [CrossRef] [PubMed] 
76. Sorlie, T.; Perou, C.M.; Tibshirani, R.; Aas, T.; Geisler, S.; Johnsen, H.; Hastie, T.; Eisen, M.B.; van de Rijn, M.; Jeffrey, S.S.; et al. Gene expression patterns of breast carcinomas distinguish tumor subclasses with clinical implications. Proc. Natl. Acad. Sci. USA 2001, 98, 10869-10874. [CrossRef] [PubMed]

77. Lund, M.J.; Butler, E.N.; Hair, B.Y.; Ward, K.C.; Andrews, J.H.; Oprea-Ilies, G.; Bayakly, A.R.; O’Regan, R.M.; Vertino, P.M.; Eley, J.W. Age/race differences in HER2 testing and in incidence rates for breast cancer triple subtypes a population-based study and first report. Cancer 2010, 116, 2549-2559. [PubMed]

78. Koboldt, D.C.; Fulton, R.S.; McLellan, M.D.; Schmidt, H.; Kalicki-Veizer, J.; McMichael, J.F.; Fulton, L.L.; Dooling, D.J.; Ding, L.; Mardis, E.R.; et al. Comprehensive molecular portraits of human breast tumours. Nature 2012, 490, 61-70. [CrossRef] [PubMed]

79. Zong, Y.; Zhu, L.; Wu, J.; Chen, X.; Huang, O.; Fei, X.; He, J.; Chen, W.; Li, Y.; Shen, K. Progesterone receptor status and Ki-67 index may predict early relapse in luminal B/HER2 negative breast cancer patients: A retrospective study. PLoS ONE 2014, 9. [CrossRef] [PubMed]

80. Samavat, H.; Kurzer, M.S. Estrogen metabolism and breast cancer. Cancer Lett. 2015, 356, 231-243. [CrossRef] [PubMed]

81. Tang, Y.; Wang, Y.; Kiani, M.F.; Wang, B. Classification, treatment strategy, and associated drug resistance in breast cancer. Clin. Breast Cancer 2016, 16, 335-343. [CrossRef] [PubMed]

82. Yang, X.R.; Chang-Claude, J.; Goode, E.L.; Couch, F.J.; Nevanlinna, H.; Milne, R.L.; Gaudet, M.; Schmidt, M.K.; Broeks, A.; Cox, A.; et al. Associations of breast cancer risk factors with tumor subtypes: A pooled analysis from the breast cancer association consortium studies. J. Natl. Cancer Inst. 2011, 103, 250-263. [CrossRef] [PubMed]

83. Atchley, D.P.; Albarracin, C.T.; Lopez, A.; Valero, V.; Amos, C.I.; Gonzalez-Angulo, A.M.; Hortobagyi, G.N.; Arun, B.K. Clinical and pathologic characteristics of patients with BRCA-positive and BRCA-negative breast cancer. J. Clin. Oncol. 2008, 26, 4282-4288. [CrossRef] [PubMed]

84. Poljsak, B.; Fink, R. The protective role of antioxidants in the defence against ROS/RNS-mediated environmental pollution. Oxid. Med. Cell. Longev. 2014. [CrossRef] [PubMed]

85. Delfino, R.J.; Staimer, N.; Vaziri, N.D. Air pollution and circulating biomarkers of oxidative stress. Air Qual. Atmos. Health 2011, 4, 37-52. [CrossRef] [PubMed]

86. Azzam, E.I.; Jay-Gerin, J.-P.; Pain, D. Ionizing radiation-induced metabolic oxidative stress and prolonged cell injury. Cancer Lett. 2012, 327, 48-60. [CrossRef] [PubMed]

87. Handy, D.E.; Loscalzo, J. Redox regulation of mitochondrial function. Antioxid. Redox Signal. 2012, 16, 1323-1367. [CrossRef] [PubMed]

88. Aon, M.A.; Cortassa, S.; O'Rourke, B. Redox-optimized ROS balance: A unifying hypothesis. Biochim. Biophys. Acta Bioenerg. 2010, 1797, 865-877. [CrossRef] [PubMed]

89. Mencalha, A.; Victorino, V.J.; Cecchini, R.; Panis, C. Mapping oxidative changes in breast cancer: Understanding the basic to reach the clinics. Anticancer Res. 2014, 34, 1127-1140. [PubMed]

90. Jezierska-Drutel, A.; Rosenzweig, S.A.; Neumann, C.A. Role of oxidative stress and the microenvironment in breast cancer development and progression. Adv. Cancer Res. 2013, 119, 107-125. [PubMed]

91. Gorrini, C.; Harris, I.S.; Mak, T.W. Modulation of oxidative stress as an anticancer strategy. Nat. Rev. Drug Discov. 2013, 12, 931-947. [CrossRef] [PubMed]

92. Hecht, F.; Pessoa, C.F.; Gentile, L.B.; Rosenthal, D.; Carvalho, D.P.; Fortunato, R.S. The role of oxidative stress on breast cancer development and therapy. Tumour Biol. 2016, 37, 4281-4291. [CrossRef] [PubMed]

93. Kupsco, A.; Schlenk, D. Oxidative stress, unfolded protein response, and apoptosis in developmental toxicity. Int. Rev. Cell Mol. Biol. 2015, 317, 1-66. [PubMed]

94. Navarro-Yepes, J.; Burns, M.; Anandhan, A.; Khalimonchuk, O.; del Razo, L.M.; Quintanilla-Vega, B.; Pappa, A.; Panayiotidis, M.I.; Franco, R. Oxidative stress, redox signaling, and autophagy: Cell death versus survival. Antioxid. Redox Signal. 2014, 21, 66-85. [CrossRef] [PubMed]

95. Samoylenko, A.; Al Hossain, J.; Mennerich, D.; Kellokumpu, S.; Hiltunen, J.K.; Kietzmann, T. Nutritional countermeasures targeting reactive oxygen species in cancer: From mechanisms to biomarkers and clinical evidence. Antioxid. Redox Signal. 2013, 19, 2157-2196. [CrossRef] [PubMed]

96. Forman, H.J.; Davies, K.J.A.; Ursini, F. How do nutritional antioxidants really work: Nucleophilic tone and para-hormesis versus free radical scavenging in vivo. Free Radic. Biol. Med. 2014, 66, 24-35. [CrossRef] [PubMed] 
97. Khan, N.; Afaq, F.; Mukhtar, H. Cancer chemoprevention through dietary antioxidants: Progress and promise. Antioxid. Redox Signal. 2008, 10, 475-510. [CrossRef] [PubMed]

98. Stoner, G.D.; Mukhtar, H. Polyphenols as cancer chemopreventive agents. J. Cell. Biochem. Suppl. 1995, 22, 169-180. [CrossRef] [PubMed]

99. Mileo, A.M.; Miccadei, S. Polyphenols as modulator of oxidative stress in cancer disease: New therapeutic strategies. Oxid. Med. Cell. Longev. 2016. [CrossRef] [PubMed]

100. Vance, T.M.; Su, J.; Fontham, E.T.H.; Koo, S.I.; Chun, O.K. Dietary antioxidants and prostate cancer: A review. Nutr. Cancer Int. J. 2013, 65, 793-801. [CrossRef] [PubMed]

101. Kim, Y.; Keogh, J.B.; Clifton, P.M. Polyphenols and glycemic control. Nutrients 2016, 8, 17. [CrossRef] [PubMed]

102. Ge, Q.; Chen, L.; Chen, K. Treatment of diabetes mellitus using ips cells and spice polyphenols. J. Diabetes Res. 2017. [CrossRef] [PubMed]

103. Khan, N.; Khymenets, O.; Urpi-Sarda, M.; Tulipani, S.; Garcia-Aloy, M.; Monagas, M.; Mora-Cubillos, X.; Llorach, R.; Andres-Lacueva, C. Cocoa polyphenols and inflammatory markers of cardiovascular disease. Nutrients 2014, 6, 844-880. [CrossRef] [PubMed]

104. Hernaez, A.; Remaley, A.T.; Farras, M.; Fernandez-Castillejo, S.; Subirana, I.; Schroeder, H.; Fernandez-Mampel, M.; Munoz-Aguayo, D.; Sampson, M.; Sola, R.; et al. Olive oil polyphenols decrease LDL concentrations and LDL atherogenicity in men in a randomized controlled trial. J. Nutr. 2015, 145, 1692-1697. [CrossRef] [PubMed]

105. Elbling, L.; Weiss, R.M.; Teufelhofer, O.; Uhl, M.; Knasmueller, S.; Schulte-Hermann, R.; Berger, W.; Mickshe, M. Green tea extract and (-)-epigallocatechin-3-gallate, the major tea catechin, exert oxidant but lack antioxidant activities. FASEB J. 2005, 19, 807-809. [CrossRef] [PubMed]

106. Hadi, S.M.; Bhat, S.H.; Azmi, A.S.; Hanif, S.; Shamim, U.; Ullah, M.F. Oxidative breakage of cellular DNA by plant polyphenols: A putative mechanism for anticancer properties. Semin. Cancer Biol. 2007, 17, 370-376. [CrossRef] [PubMed]

107. Decker, E.A. Phenolics: Prooxidants or antioxidants? Nutr. Rev. 1997, 55, 396-398. [CrossRef] [PubMed]

108. Li, Y.; Trush, M.A. Reactive oxygen-dependent DNA damage resulting from the oxidation of phenolic compounds by a copper-redox cycle mechanism. Cancer Res. 1994, 54, 1895s-1898s. [PubMed]

109. Denoyer, D.; Masaldan, S.; La Fontaine, S.; Cater, M.A. Targeting copper in cancer therapy: 'Copper that cancer'. Metallomics 2015, 7, 1459-1476. [CrossRef] [PubMed]

110. Khan, H.Y.; Zubair, H.; Faisal, M.; Ullah, M.F.; Farhan, M.; Sarkar, F.H.; Ahmad, A.; Hadi, S.M. Plant polyphenol induced cell death in human cancer cells involves mobilization of intracellular copper ions and reactive oxygen species generation: A mechanism for cancer chemopreventive action. Mol. Nutr. Food Res. 2014, 58, 437-446. [CrossRef] [PubMed]

111. Bower, J.J.; Vance, L.D.; Psioda, M.; Smith-Roe, S.L.; Simpson, D.A.; Ibrahim, J.G.; Hoadley, K.A.; Perou, C.M.; Kaufmann, W.K. Patterns of cell cycle checkpoint deregulation associated with intrinsic molecular subtypes of human breast cancer cells. NPJ Breast Cancer 2017, 3, 9. [CrossRef] [PubMed]

112. Hanahan, D.; Weinberg, R.A. Hallmarks of cancer: The next generation. Cell 2011, 144, 646-674. [CrossRef] [PubMed]

113. Oikonomou, C.; Cross, F.R. Rising cyclin-CDK levels order cell cycle events. PLoS ONE 2011, 6, e20788. [CrossRef] [PubMed]

114. Duronio, R.J.; Xiong, Y. Signaling pathways that control cell proliferation. Cold Spring Harb. Perspect. Biol. 2013, 5. [CrossRef] [PubMed]

115. Shin, S.Y.; Yoon, H.; Ahn, S.; Kim, D.-W.; Bae, D.-H.; Koh, D.; Lee, Y.H.; Lim, Y. Structural properties of polyphenols causing cell cycle arrest at G1 phase in HCT116 human colorectal cancer cell lines. Int. J. Mol. Sci. 2013, 14, 16970-16985. [CrossRef] [PubMed]

116. Zhao, Q.; Huo, X.-C.; Sun, F.-D.; Dong, R.-Q. Polyphenol-rich extract of salvia chinensis exhibits anticancer activity in different cancer cell lines, and induces cell cycle arrest at the $\mathrm{G}(0) / \mathrm{G}(1)$-phase, apoptosis and loss of mitochondrial membrane potential in pancreatic cancer cells. Mol. Med. Rep. 2015, 12, 4843-4850. [CrossRef] [PubMed]

117. Gonzalez-Sarrias, A.; Ma, H.; Edmonds, M.E.; Seeram, N.P. Maple polyphenols, ginnalins A-C, induce Sand G2/M-cell cycle arrest in colon and breast cancer cells mediated by decreasing cyclins A and D1 levels. Food Chem. 2013, 136, 636-642. [CrossRef] [PubMed] 
118. Liu, S.-M.; Ou, S.-Y.; Huang, H.-H. Green tea polyphenols induce cell death in breast cancer MCF-7 cells through induction of cell cycle arrest and mitochondrial-mediated apoptosis. J. Zhejiang Univ. Sci. B 2017, 18, 89-98. [CrossRef] [PubMed]

119. Li, T.; Zhu, J.; Guo, L.; Shi, X.; Liu, Y.; Yang, X. Differential effects of polyphenols-enriched extracts from hawthorn fruit peels and fleshes on cell cycle and apoptosis in human MCF-7 breast carcinoma cells. Food Chem. 2013, 141, 1008-1018. [CrossRef] [PubMed]

120. Chen, H.-S.; Bai, M.-H.; Zhang, T.; Li, G.-D.; Liu, M. Ellagic acid induces cell cycle arrest and apoptosis through TGF-beta/Smad3 signaling pathway in human breast cancer MCF-7 cells. Int. J. Oncol. 2015, 46, 1730-1738. [CrossRef] [PubMed]

121. Elmore, S. Apoptosis: A review of programmed cell death. Toxicol. Pathol. 2007, 35, 495-516. [CrossRef] [PubMed]

122. Nagasaka, A.; Kawane, K.; Yoshida, H.; Nagata, S. Apaf-1-independent programmed cell death in mouse development. Cell Death Differ. 2010, 17, 931-941. [CrossRef] [PubMed]

123. Burgess, D.J. Apoptosis refined and lethal. Nat. Rev. Cancer 2013, 13, 79. [CrossRef] [PubMed]

124. Miyashita, T.; Krajewski, S.; Krajewska, M.; Wang, H.G.; Lin, H.K.; Liebermann, D.A.; Hoffman, B.; Reed, J.C. Tumor-suppressor p53 is a regulator of bcl-2 and bax gene-expression in vitro in vitro and in vivo in vivo. Oncogene 1994, 9, 1799-1805. [PubMed]

125. Muller, P.A.J.; Vousden, K.H. Mutant p53 in cancer: New functions and therapeutic opportunities. Cancer Cell 2014, 25, 304-317. [CrossRef] [PubMed]

126. Jahanafrooz, Z.; Motameh, N.; Bakhshandeh, B. Comparative evaluation of silibinin effects on cell cycling and apoptosis in human breast cancer MCF-7 and T47D cell lines. Asian Pac. J. Cancer Prev. APJCP 2016, 17, 2661-2665. [PubMed]

127. Song, M.S.; Salmena, L.; Pandolfi, P.P. The functions and regulation of the PTEN tumour suppressor. Nat. Rev. Mol. Cell Biol. 2012, 13, 283-296. [CrossRef] [PubMed]

128. Gartel, A.L.; Tyner, A.L. The role of the cyclin-dependent kinase inhibitor p21 in apoptosis. Mol. Cancer Ther. 2002, 1, 639-649. [PubMed]

129. D'Angelo, S.; Martino, E.; Ilisso, C.P.; Bagarolo, M.L.; Porcelli, M.; Cacciapuoti, G. Pro-oxidant and pro-apoptotic activity of polyphenol extract from annurca apple and its underlying mechanisms in human breast cancer cells. Int. J. Oncol. 2017, 51, 939-948. [CrossRef] [PubMed]

130. Kello, M.; Kulikova, L.; Vaskova, J.; Nagyova, A.; Mojzis, J. Fruit peel polyphenolic extract-induced apoptosis in human breast cancer cells is associated with ros production and modulation of p38MAPK/ERK1/2 and the akt signaling pathway. Nutr. Cancer 2017, 69, 920-931. [CrossRef] [PubMed]

131. Hassan, Z.K.; Elamin, M.H.; Omer, S.A.; Daghestani, M.H.; Al-Olayan, E.S.; Elobeid, M.A.; Virk, P. Oleuropein induces apoptosis via the p53 pathway in breast cancer cells. Asian Pac. J. Cancer Prev. 2013, 14, 6739-6742. [CrossRef]

132. Yan, C.-M.; Chai, E.-Q.; Cai, H.-Y.; Miao, G.-Y.; Ma, W. Oleuropein induces apoptosis via activation of caspases and suppression of phosphatidylinositol 3-kinase/protein kinase B pathway in HepG2 human hepatoma cell line. Mol. Med. Rep. 2015, 11, 4617-4624. [CrossRef] [PubMed]

133. Meeran, S.M.; Patel, S.N.; Chan, T.H.; Tollefsbol, T.O. A novel prodrug of epigallocatechin-3-gallate: Differential epigenetic hTERT repression in human breast cancer cells. Cancer Prev. Res. 2011, 4, 1243-1254. [CrossRef] [PubMed]

134. Jaiswal, P.K.; Goel, A.; Mittal, R.D. Survivin: A molecular biomarker in cancer. Indian J. Med. Res. 2015, 141, 389-397. [PubMed]

135. Chen, X.; Li, Y.; Lin, Q.; Wang, Y.; Sun, H.; Wang, J.; Cui, G.; Cai, L.; Dong, X. Tea polyphenols induced apoptosis of breast cancer cells by suppressing the expression of Survivin. Sci. Rep. 2014, 4. [CrossRef] [PubMed]

136. Thangapazham, R.L.; Passi, N.; Maheshwari, R.K. Green tea polyphenol and epigallocatechin gallate induce apoptosis and inhibit invasion in human breast cancer cells. Cancer Biol. Ther. 2007, 6, 1938-1943. [CrossRef] [PubMed]

137. Mileo, A.M.; Di Venere, D.; Linsalata, V.; Fraioli, R.; Miccadei, S. Artichoke polyphenols induce apoptosis and decrease the invasive potential of the human breast cancer cell line MDA-MB231. J. Cell. Physiol. 2012, 227, 3301-3309. [CrossRef] [PubMed] 
138. Mileo, A.M.; Di Venere, D.; Abbruzzese, C.; Miccadei, S. Long term exposure to polyphenols of artichoke (Cynara scolymus L.) exerts induction of senescence driven growth arrest in the MDA-MB231 human breast cancer cell line. Oxid. Med. Cell. Longev. 2015. [CrossRef] [PubMed]

139. Venkatadri, R.; Muni, T.; Iyer, A.K.V.; Yakisich, J.S.; Azad, N. Role of apoptosis-related miRNAs in resveratrol-induced breast cancer cell death. Cell Death Dis. 2016, 7. [CrossRef] [PubMed]

140. Srivastava, S.; Somasagara, R.R.; Hegde, M.; Nishana, M.; Tadi, S.K.; Srivastava, M.; Choudhary, B.; Raghavan, S.C. Quercetin, a natural flavonoid interacts with DNA, arrests cell cycle and causes tumor regression by activating mitochondrial pathway of apoptosis. Sci. Rep. 2016, 6. [CrossRef] [PubMed]

141. Afsar, T.; Trembley, J.H.; Salomon, C.E.; Razak, S.; Khan, M.R.; Ahmed, K. Growth inhibition and apoptosis in cancer cells induced by polyphenolic compounds of Acacia hydaspica: Involvement of multiple signal transduction pathways. Sci. Rep. 2016, 6. [CrossRef] [PubMed]

142. Castillo-Pichardo, L.; Dharmawardhane, S.F. Grape polyphenols inhibit Akt/mammalian target of rapamycin signaling and potentiate the effects of gefitinib in breast cancer. Nutr. Cancer Int. J. 2012, 64, 1058-1069. [CrossRef] [PubMed]

143. Galluzzi, L.; Pietrocola, F.; Bravo-San Pedro, J.M.; Amaravadi, R.K.; Baehrecke, E.H.; Cecconi, F.; Codogno, P.; Debnath, J.; Gewirtz, D.A.; Karantza, V.; et al. Autophagy in malignant transformation and cancer progression. EMBO J. 2015, 34, 856-880. [CrossRef] [PubMed]

144. Villar, V.H.; Merhi, F.; Djavaheri-Mergny, M.; Duran, R.V. Glutaminolysis and autophagy in cancer. Autophagy 2015, 11, 1198-1208. [CrossRef] [PubMed]

145. Mah, L.Y.; Ryan, K.M. Autophagy and cancer. Cold Spring Harb. Perspect. Biol. 2012, 4. [CrossRef] [PubMed]

146. Yang, Y.; Coleman, M.; Zhang, L.; Zheng, X.; Yue, Z. Autophagy in axonal and dendritic degeneration. Trends Neurosci. 2013, 36, 418-428. [CrossRef] [PubMed]

147. Plaza-Zabala, A.; Sierra-Torre, V.; Sierra, A. Autophagy and microglia: Novel partners in neurodegeneration and aging. Int. J. Mol. Sci. 2017, 18, 598. [CrossRef] [PubMed]

148. Xilouri, M.; Stefanis, L. Chaperone mediated autophagy in aging: Starve to prosper. Ageing Res. Rev. 2016, 32, 13-21. [CrossRef] [PubMed]

149. Chauhan, S.; Mandell, M.A.; Deretic, V. IRGM governs the core autophagy machinery to conduct antimicrobial defense. Mol. Cell 2015, 58, 507-521. [CrossRef] [PubMed]

150. Chiu, H.-C.; Soni, S.; Kulp, S.K.; Curry, H.; Wang, D.; Gunn, J.S.; Schlesinger, L.S.; Chen, C.-S. Eradication of intracellular francisella tularensis in THP-1 human macrophages with a novel autophagy inducing agent. J. Biomed. Sci. 2009, 16. [CrossRef] [PubMed]

151. Hasima, N.; Ozpolat, B. Regulation of autophagy by polyphenolic compounds as a potential therapeutic strategy for cancer. Cell Death Dis. 2014, 5. [CrossRef] [PubMed]

152. Mathew, R.; Karantza-Wadsworth, V.; White, E. Role of autophagy in cancer. Nat. Rev. Cancer 2007, 7, 961-967. [CrossRef] [PubMed]

153. Huang, H.-C.; Syu, K.-Y.; Lin, J.-K. Chemical composition of solanum nigrum linn extract and induction of autophagy by leaf water extract and its major flavonoids in AU565 breast cancer cells. J. Agric. Food Chem. 2010, 58, 8699-8708. [CrossRef] [PubMed]

154. Adams, L.S.; Phung, S.; Yee, N.; Seeram, N.P.; Li, L.; Chen, S. Blueberry phytochemicals inhibit growth and metastatic potential of MDA-MB-231 breast cancer cells through modulation of the phosphatidylinositol 3-kinase pathway. Cancer Res. 2010, 70, 3594-3605. [CrossRef] [PubMed]

155. Sun, T.; Chen, Q.Y.; Wu, L.J.; Yao, X.M.; Sun, X.J. Antitumor and antimetastatic activities of grape skin polyphenols in a murine model of breast cancer. Food Chem. Toxicol. 2012, 50, 3462-3467. [CrossRef] [PubMed]

156. Nemec, M.J.; Kim, H.; Marciante, A.B.; Barnes, R.C.; Hendrick, E.D.; Bisson, W.H.; Talcott, S.T.; Mertens-Talcott, S.U. Polyphenolics from mango (Mangifera indica L.) suppress breast cancer ductal carcinoma in situ proliferation through activation of AMPK pathway and suppression of mTOR in athymic nude mice. J. Nutr. Biochem. 2017, 41, 12-19. [CrossRef] [PubMed]

157. Tanida, I.; Ueno, T.; Kominami, E. LC3 and autophagy. Methods Mol. Biol. 2008, 445, 77-88. [PubMed]

158. Scarlatti, F.; Maffei, R.; Beau, I.; Codogno, P.; Ghidoni, R. Role of non-canonical Beclin 1-independent autophagy in cell death induced by resveratrol in human breast cancer cells. Cell Death Differ. 2008, 15, 1318-1329. [CrossRef] [PubMed] 
159. Zhang, L.; Shamaladevi, N.; Jayaprakasha, G.K.; Patil, B.S.; Lokeshwar, B.L. Polyphenol-rich extract of pimenta dioica berries (allspice) kills breast cancer cells by autophagy and delays growth of triple negative breast cancer in athymic mice. Oncotarget 2015, 6, 16379-16395. [CrossRef] [PubMed]

160. Al Dhaheri, Y.; Attoub, S.; Ramadan, G.; Arafat, K.; Bajbouj, K.; Karuvantevida, N.; AbuQamar, S.; Eid, A.; Iratni, R. Carnosol induces ROS-mediated Beclin1-independent autophagy and apoptosis in triple negative breast cancer. PLoS ONE 2014, 9. [CrossRef] [PubMed]

161. Fu, Y.; Chang, H.; Peng, X.; Bai, Q.; Yi, L.; Zhou, Y.; Zhu, J.; Mi, M. Resveratrol inhibits breast cancer stem-like cells and induces autophagy via suppressing Wnt/beta-catenin signaling pathway. PLoS ONE 2014, 9. [CrossRef]

162. Samadi, A.K.; Bilsland, A.; Georgakilas, A.G.; Amedei, A.; Amin, A.; Bishayee, A.; Azmi, A.S.; Lokeshwar, B.L.; Grue, B.; Panis, C.; et al. A multi-targeted approach to suppress tumor-promoting inflammation. Semin. Cancer Biol. 2015, 35, S151-S184. [CrossRef] [PubMed]

163. Thompson, P.A.; Khatami, M.; Baglole, C.J.; Sun, J.; Harris, S.; Moon, E.-Y.; Al-Mulla, F.; Al-Temaimi, R.; Brown, D.; Colacci, A.; et al. Environmental immune disruptors, inflammation and cancer risk. Carcinogenesis 2015, 36, S232-S253. [CrossRef] [PubMed]

164. Demaria, S.; Pikarsky, E.; Karin, M.; Coussens, L.M.; Chen, Y.-C.; El-Omar, E.M.; Trinchieri, G.; Dubinett, S.M.; Mao, J.T.; Szabo, E.; et al. Cancer and inflammation: Promise for biologic therapy. J. Immunother. 2010, 33, 335-351. [CrossRef] [PubMed]

165. Pinho, A.V.; Chantrill, L.; Rooman, I. Chronic pancreatitis: A path to pancreatic cancer. Cancer Lett. 2014, 345, 203-209. [CrossRef] [PubMed]

166. Higashi, D.; Futami, K.; Kojima, D.; Futatsuki, R.; Ishibashi, Y.; Maekawa, T.; Yano, Y.; Takatsu, N.; Hirai, F.; Matsui, T.; et al. Cancer of the small intestine in patients with crohn's disease. Anticancer Res. 2013, 33, 2977-2980. [PubMed]

167. Tu, T.; Buhler, S.; Bartenschlager, R. Chronic viral hepatitis and its association with liver cancer. Biol. Chem. 2017, 398, 817-837. [CrossRef] [PubMed]

168. Wei, X.L.; Luo, H.Y.; Li, C.F.; Jin, Y.; Zeng, Z.L.; Ju, H.Q.; Wu, Q.N.; Wang, Y.; Mao, M.J.; Liu, W.L.; et al. Hepatitis $B$ virus infection is associated with younger median age at diagnosis and death in cancers. Int. J. Cancer 2017, 141, 152-159. [CrossRef] [PubMed]

169. Kolb, J.M.; Ozbek, U.; Harpaz, N.; Holcombe, R.F.; Ang, C. Effect of helicobacter pylori infection on outcomes in resected gastric and gastroesophageal junction cancer. J. Gastrointest. Oncol. 2017, 8, 583-588. [CrossRef] [PubMed]

170. Lee, Y.C.; Lin, J.T. Screening and treating Helicobacter pylori infection for gastric cancer prevention on the population level. J. Gastroenterol. Hepatol. 2017, 32, 1160-1169. [CrossRef] [PubMed]

171. Wang, T.Y.; Cai, H.; Zheng, W.; Michel, A.; Pawlita, M.; Milne, G.; Xiang, Y.B.; Gao, Y.T.; Li, H.L.; Rothman, N.; et al. A prospective study of urinary prostaglandin $\mathrm{E} 2$ metabolite, helicobacter pylori antibodies, and gastric cancer risk. Clin. Infect. Dis. 2017, 64, 1380-1386. [CrossRef] [PubMed]

172. Greten, F.R.; Eckmann, L.; Greten, T.F.; Park, J.M.; Li, Z.W.; Egan, L.J.; Kagnoff, M.F.; Karin, M. IKKbeta links inflammation and tumorigenesis in a mouse model of colitis-associated cancer. Cell 2004, 118, 285-296. [CrossRef] [PubMed]

173. Coussens, L.M.; Werb, Z. Inflammation and cancer. Nature 2002, 420, 860-867. [CrossRef] [PubMed]

174. Meira, L.B.; Bugni, J.M.; Green, S.L.; Lee, C.-W.; Pang, B.; Borenshtein, D.; Rickman, B.H.; Rogers, A.B.; Moroski-Erkul, C.A.; McFaline, J.L.; et al. DNA damage induced by chronic inflammation contributes to colon carcinogenesis in mice. J. Clin. Investig. 2008, 118, 2516-2525. [CrossRef] [PubMed]

175. Benvenuto, M.; Fantini, M.; Masuelli, L.; De Smaele, E.; Zazzeroni, F.; Tresoldi, I.; Calabrese, G.; Galvano, F.; Modesti, A.; Bei, R. Inhibition of ErbB receptors, hedgehog and NF-kappaB signaling by polyphenols in cancer. Front. Biosci. Landmark 2013, 18, 1291-1311.

176. Ferruelo, A.; de las Heras, M.M.; Redondo, C.; Ramon de Fata, F.; Romero, I.; Angulo, J.C. Wine polyphenols exert antineoplasic effect on androgen resistant PC-3 cell line through the inhibition of the transcriptional activity of COX-2 promoter mediated by NF-k beta. Actas Urol. Esp. 2014, 38, 429-437. [CrossRef] [PubMed]

177. Willenberg, I.; Meschede, A.K.; Gueler, F.; Jang, M.-S.; Shushakova, N.; Schebb, N.H. Food polyphenols fail to cause a biologically relevant reduction of COX-2 activity. PLOS ONE 2015, 10. [CrossRef] [PubMed] 
178. Lilia Salas, A.; Rosa Alberto, M.; Catiana Zampini, I.; Soledad Cuello, A.; Maldonado, L.; Luis Rios, J.; Schmeda-Hirschmann, G.; Ines Isla, M. Biological activities of polyphenols-enriched propolis from argentina arid regions. Phytomedicine 2016, 23, 27-31. [CrossRef] [PubMed]

179. Yang, F.; Suo, Y.; Chen, D.; Tong, L. Protection against vascular endothelial dysfunction by polyphenols in sea buckthorn berries in rats with hyperlipidemia. Biosci. Trends 2016, 10, 188-196. [CrossRef] [PubMed]

180. Surh, Y.-J.; Chun, K.-S.; Cha, H.-H.; Han, S.S.; Keum, Y.-S.; Park, K.-K.; Lee, S.S. Molecular mechanisms underlying chemopreventive activities of anti-inflammatory phytochemicals: Down-regulation of COX-2 and iNOS through suppression of NF-kb activation. Mutat. Res. Fundam. Mol. Mech. Mutagen. 2001, 480-481, 243-268. [CrossRef]

181. Rodriguez-Ramiro, I.; Ramos, S.; Lopez-Oliva, E.; Agis-Torres, A.; Bravo, L.; Goya, L.; Angeles Martin, M. Cocoa polyphenols prevent inflammation in the colon of azoxymethane-treated rats and in TNF-alpha-stimulated Caco-2 cells. Br. J. Nutr. 2013, 110, 206-215. [CrossRef] [PubMed]

182. Banerjee, N.; Talcott, S.; Safe, S.; Mertens-Talcott, S.U. Cytotoxicity of pomegranate polyphenolics in breast cancer cells in vitro and vivo: Potential role of miRNA-27a and miRNA-155 in cell survival and inflammation. Breast Cancer Res. Treat. 2012, 136, 21-34. [CrossRef] [PubMed]

183. Mandal, A.; Bhatia, D.; Bishayee, A. Anti-inflammatory mechanism involved in pomegranate-mediated prevention of breast cancer: The role of NF-kappab and Nrf2 signaling pathways. Nutrients 2017, 9, 436. [CrossRef] [PubMed]

184. Vuong, T.; Mallet, J.-F.; Ouzounova, M.; Rahbar, S.; Hernandez-Vargas, H.; Herceg, Z.; Matar, C. Role of a polyphenol-enriched preparation on chemoprevention of mammary carcinoma through cancer stem cells and inflammatory pathways modulation. J. Transl. Med. 2016, 14. [CrossRef] [PubMed]

185. Kang, H.K.; Choi, Y.-H.; Kwon, H.; Lee, S.-B.; Kim, D.-H.; Sung, C.K.; Park, Y.I.; Dong, M.-S. Estrogenic/antiestrogenic activities of a Epimedium koreanum extract and its major components: In vitro and in vivo studies. Food Chem. Toxicol. 2012, 50, 2751-2759. [CrossRef] [PubMed]

186. Camargo, M.S.; Prieto, A.M.; Resende, F.A.; Boldrin, P.K.; Cardoso, C.R.P.; Fernandez, M.F.; Molina-Molina, J.M.; Olea, N.; Vilegas, W.; Cuesta-Rubio, O.; et al. Evaluation of estrogenic, antiestrogenic and genotoxic activity of nemorosone, the major compound found in brown Cuban propolis. BMC Complement. Altern. Med. 2013, 13. [CrossRef] [PubMed]

187. Collins-Burow, B.M.; Antoon, J.W.; Frigo, D.E.; Elliott, S.; Weldon, C.B.; Boue, S.M.; Beckman, B.S.; Curiel, T.J.; Alam, J.; McLachlan, J.A.; et al. Antiestrogenic activity of flavonoid phytochemicals mediated via the c-jun $\mathrm{N}$-terminal protein kinase pathway. Cell-type specific regulation of estrogen receptor alpha. J. Steroid Biochem. Mol. Biol. 2012, 132, 186-193. [CrossRef] [PubMed]

188. Korobkova, E.A. Effect of natural polyphenols on CYP metabolism: Implications for diseases. Chem. Res. Toxicol. 2015, 28, 1359-1390. [CrossRef] [PubMed]

189. Yiannakopoulou, E.C. Interaction of green tea catechins with breast cancer endocrine treatment: A systematic review. Pharmacology 2014, 94, 245-248. [CrossRef] [PubMed]

190. Way, T.D.; Lee, H.H.; Kao, M.C.; Lin, J.K. Black tea polyphenol theaflavins inhibit aromatase activity and attenuate tamoxifen resistance in HER2/neu-transfected human breast cancer cells through tyrosine kinase suppression. Eur. J. Cancer 2004, 40, 2165-2174. [CrossRef] [PubMed]

191. Griffiths, K.; Wilson, D.W.; Singh, R.B.; De Meester, F. Effect of dietary phytoestrogens on human growth regulation: Imprinting in health \& disease. Indian J. Med. Res. 2014, 140, 82-90.

192. Patisaul, H.B.; Jefferson, W. The pros and cons of phytoestrogens. Front. Neuroendocrinol. 2010, 31, 400-419. [CrossRef] [PubMed]

193. Lee, Y.M.; Kim, J.B.; Bae, J.H.; Lee, J.S.; Kim, P.-S.; Jang, H.H.; Kim, H.R. Estrogen-like activity of aqueous extract from agrimonia pilosa ledeb. in MCF-7 cells. BMC Complement. Altern. Med. 2012, 12. [CrossRef] [PubMed]

194. Paterni, I.; Granchi, C.; Katzenellenbogen, J.A.; Minutolo, F. Estrogen receptors alpha (ER $\alpha)$ and beta (ER $\beta)$ : Subtype-selective ligands and clinical potential. Steroids 2014, 90, 13-29. [CrossRef] [PubMed]

195. Chalopin, M.; Tesse, A.; Martinez, M.C.; Rognan, D.; Arnal, J.-F.; Andriantsitohaina, R. Estrogen receptor alpha as a key target of red wine polyphenols action on the endothelium. PLoS ONE 2010, 5. [CrossRef] [PubMed] 
196. Albini, A.; Rosano, C.; Angelini, G.; Amaro, A.; Esposito, A.I.; Maramotti, S.; Noonan, D.M.; Pfeffer, U. Exogenous hormonal regulation in breast cancer cells by phytoestrogens and endocrine disruptors. Curr. Med. Chem. 2014, 21, 1129-1145. [CrossRef] [PubMed]

197. Lambrinidis, G.; Halabalaki, M.; Katsanou, E.S.; Skaltsounis, A.L.; Alexis, M.N.; Mikros, E. The estrogen receptor and polyphenols: Molecular simulation studies of their interactions, a review. Environ. Chem. Lett. 2006, 4, 159-174. [CrossRef]

198. De Amicis, F.; Russo, A.; Avena, P.; Santoro, M.; Vivacqua, A.; Bonofiglio, D.; Mauro, L.; Aquila, S.; Tramontano, D.; Fuqua, S.A.W.; et al. In vitro mechanism for downregulation of ER-alpha expression by epigallocatechin gallate in ER+/PR+ human breast cancer cells. Mol. Nutr. Food Res. 2013, 57, 840-853. [CrossRef] [PubMed]

199. Hallman, K.; Aleck, K.; Quigley, M.; Dwyer, B.; Lloyd, V.; Szmyd, M.; Dinda, S. The regulation of steroid receptors by epigallocatechin-3-gallate in breast cancer cells. Breast Cancer Targets Ther. 2017, 9, 365-373. [CrossRef] [PubMed]

200. Bak, M.J.; Das Gupta, S.; Wahler, J.; Suh, N. Role of dietary bioactive natural products in estrogen receptor-positive breast cancer. Semin. Cancer Biol. 2016, 40-41, 170-191. [CrossRef] [PubMed]

201. Wang, Y.; Gho, W.M.; Chan, F.L.; Chen, S.; Leung, L.K. The red clover (Trifolium pratense) isoflavone biochanin a inhibits aromatase activity and expression. Br. J. Nutr. 2008, 99, 303-310. [CrossRef] [PubMed]

202. Wang, Y.; Lee, K.W.; Chan, F.L.; Chen, S.A.; Leung, L.K. The red wine polyphenol resveratrol displays bilevel inhibition on aromatase in breast cancer cells. Toxicol. Sci. 2006, 92, 71-77. [CrossRef] [PubMed]

203. Lan, Y.; Gho, W.M.; Chan, F.L.; Chen, S.; Leung, L.K. Dietary administration of the licorice flavonoid isoliquiritigenin deters growth of MCF-7 cells overexpressing aromatase. Int. J. Cancer 2009, 124, 1028-1036. [CrossRef]

204. Moseley, V.R.; Morris, J.; Knackstedt, R.W.; Wargovich, M.J. Green tea polyphenol epigallocatechin 3-gallate, contributes to the degradation of DNMT3A and HDAC3 in HCT 116 human colon cancer cells. Anticancer Res. 2013, 33, 5325-5333. [PubMed]

205. Kang, I.; Okla, M.; Chung, S. Ellagic acid inhibits adipocyte differentiation through coactivator-associated arginine methyltransferase 1-mediated chromatin modification. J. Nutr. Biochem. 2014, 25, 946-953. [CrossRef] [PubMed]

206. Fang, M.; Chen, D.; Yang, C.S. Dietary polyphenols may affect DNA methylation. J. Nutr. 2007, 137, 223S-228S. [PubMed]

207. Pathiraja, T.N.; Stearns, V.; Oesterreich, S. Epigenetic regulation in estrogen receptor positive breast cancer-role in treatment response. J. Mammary Gland Biol. Neoplasia 2010, 15, 35-47. [CrossRef] [PubMed]

208. Meeran, S.M.; Patel, S.N.; Li, Y.; Shukla, S.; Tollefsbol, T.O. Bioactive dietary supplements reactivate ER expression in ER-negative breast cancer cells by active chromatin modifications. PLoS ONE 2012, 7. [CrossRef] [PubMed]

209. Carpenter, R.L.; Lo, H.-W. Regulation of apoptosis by HER2 in breast cancer. J. Carcinog. Mutagen. $2013,2013$. [CrossRef]

210. Zhou, B.H.P.; Liao, Y.; Xia, W.Y.; Zou, Y.Y.; Spohn, B.; Hung, M.C. HER-2/neu induces p53 ubiquitination via Akt-mediated MDM2 phosphorylation. Nat. Cell Biol. 2001, 3, 973-982. [CrossRef] [PubMed]

211. Siddiqa, A.; Long, L.M.; Li, L.; Marciniak, R.A.; Kazhdan, I. Expression of HER-2 in MCF-7 breast cancer cells modulates anti-apoptotic proteins survivin and Bcl-2 via the extracellular signal-related kinase (ERK) and phosphoinositide-3 kinase (PI3K) signalling pathways. BMC Cancer 2008, 8. [CrossRef] [PubMed]

212. Boekhout, A.H.; Beijnen, J.H.; Schellens, J.H.M. Trastuzumab. Oncologist 2011, 16, 800-810. [CrossRef] [PubMed]

213. Menendez, J.A.; Vazquez-Martin, A.; Colomer, R.; Brunet, J.; Carrasco-Pancorbo, A.; Garcia-Villalba, R.; Fernandez-Gutierrez, A.; Segura-Carretero, A. Olive oil's bitter principle reverses acquired autoresistance to trastuzumab (herceptin ${ }^{\mathrm{TM}}$ ) in HER2-overexpressing breast cancer cells. BMC Cancer 2007, 7. [CrossRef] [PubMed]

214. Menendez, J.A.; Vazquez-Martin, A.; Garcia-Villalba, R.; Carrasco-Pancorbo, A.; Oliveras-Ferraros, C.; Fernandez-Gutierrez, A.; Segura-Carretero, A. Tabanti-HER2 (erbB-2) oncogene effects of phenolic compounds directly isolated from commercial Extra-Virgin Olive Oil (EVOO). BMC Cancer 2008, 8. [CrossRef] [PubMed] 
215. Mahmoodi, N.; Motamed, N.; Paylakhi, S.H.; Mahmoodi, N.O. Comparing the effect of silybin and silybin advanced ( $\mathrm{tm}$ ) on viability and HER2 expression on the human breast cancer SKBR3 cell line by no serum starvation. Iranian J. Pharm. Res. 2015, 14, 521-530.

216. Way, T.D.; Kao, M.C.; Lin, J.K. Apigenin induces apoptosis through proteasomal degradation of HER2/neu in HER2/neu-overexpressing breast cancer cells via the phosphatidylinositol 3-kinase/Akt-dependent pathway. J. Biol. Chem. 2004, 279, 4479-4489. [CrossRef] [PubMed]

217. Lai, H.-W.; Chien, S.-Y.; Kuo, S.-J.; Tseng, L.-M.; Lin, H.-Y.; Chi, C.-W.; Chen, D.-R. The potential utility of curcumin in the treatment of HER-2-overexpressed breast cancer: An in vitro and in vivo comparison study with herceptin. Evid.-Based Complement. Altern. Med. 2012. [CrossRef]

218. Sidera, K.; Gaitanou, M.; Stellas, D.; Matsas, R.; Patsavoudi, E. A critical role for HSP90 in cancer cell invasion involves interaction with the extracellular domain of HER-2. J. Biol. Chem. 2008, 283, 2031-2041. [CrossRef] [PubMed]

219. Citri, A.; Harari, D.; Shohat, G.; Ramakrishnan, P.; Gan, J.; Lavi, S.; Eisenstein, M.; Kimchi, A.; Wallach, D.; Pietrokovski, S.; et al. Hsp90 recognizes a common surface on client kinases. J. Biol. Chem. 2006, 281, 14361-14369. [CrossRef] [PubMed]

220. Garcia-Carbonero, R.; Carnero, A.; Paz-Ares, L. Inhibition of HSP90 molecular chaperones: Moving into the clinic. Lancet Oncol. 2013, 14, E358-E369. [CrossRef]

221. Yan, Y.-Y.; Zheng, L.-S.; Zhang, X.; Chen, L.-K.; Singh, S.; Wang, F.; Zhang, J.-Y.; Liang, Y.-J.; Dai, C.-L.; Gu, L.-Q.; et al. Blockade of HER2/neu binding to HSP90 by emodin azide methyl anthraquinone derivative induces proteasomal degradation of HER2/neu. Mol. Pharm. 2011, 8, 1687-1697. [CrossRef] [PubMed]

222. Chiang, C.-T.; Way, T.-D.; Lin, J.-K. Sensitizing HER2-overexpressing cancer cells to luteolin-induced apoptosis through suppressing p21(WAF1/CLP1) expression with rapamycin. Mol. Cancer Ther. 2007, 6, 2127-2138. [CrossRef] [PubMed]

223. Vassallo, A.; Vaccaro, M.C.; De Tommasi, N.; Dal Piaz, F.; Leone, A. Identification of the plant compound geraniin as a novel Hsp90 inhibitor. PLoS ONE 2013, 8. [CrossRef] [PubMed]

224. Giommarelli, C.; Zuco, V.; Favini, E.; Pisano, C.; Dal Piaz, F.; De Tommasi, N.; Zunino, F. The enhancement of antiproliferative and proapoptotic activity of HDAC inhibitors by curcumin is mediated by Hsp90 inhibition. Cell. Mol. Life Sci. 2010, 67, 995-1004. [CrossRef] [PubMed]

225. Moses, M.A.; Henry, E.C.; Ricke, W.A.; Gasiewicz, T.A. The heat shock protein 90 inhibitor, (-)-epigallocatechin gallate, has anticancer activity in a novel human prostate cancer progression model. Cancer Prev. Res. 2015, 8, 249-257. [CrossRef] [PubMed]

226. Menendez, J.A.; Lupu, R. Fatty acid synthase and the lipogenic phenotype in cancer pathogenesis. Nat. Rev. Cancer 2007, 7, 763-777. [CrossRef] [PubMed]

227. Yoon, S.; Lee, M.-Y.; Park, S.W.; Moon, J.-S.; Koh, Y.-K.; Ahn, Y.-H.; Park, B.-W.; Kim, K.-S. Up-regulation of acetyl-CoA carboxylase alpha and fatty acid synthase by human epidermal growth factor receptor 2 at the translational level in breast cancer cells. J. Biol. Chem. 2007, 282, 26122-26131. [CrossRef] [PubMed]

228. Pizer, E.S.; Thupari, J.; Han, W.F.; Pinn, M.L.; Chrest, F.J.; Frehywot, G.L.; Townsend, C.A.; Kuhajda, F.P. Malonyl-coenzyme-A is a potential mediator of cytotoxicity induced by fatty-acid synthase inhibition in human breast cancer cells and xenograft. Cancer Res. 2000, 60, 213-218. [PubMed]

229. Zhou, W.; Tu, Y.; Simpson, P.J.; Kuhajda, F.P. Malonyl-CoA decarboxylase inhibition is selectively cytotoxic to human breast cancer cells. Oncogene 2009, 28, 2979-2987. [CrossRef] [PubMed]

230. Thupari, J.N.; Pinn, M.L.; Kuhajda, F.P. Fatty acid synthase inhibition in human breast cancer cells leads to malonyl-CoA-induced inhibition of fatty acid oxidation and cytotoxicity. Biochem. Biophys. Res. Commun. 2001, 285, 217-223. [CrossRef] [PubMed]

231. Younesian, O.; Kazerouni, F.; Dehghan-Nayeri, N.; Omrani, D.; Rahimipour, A.; Shanaki, M.; Kalkhoran, M.R.; Cheshmi, F. Effect of curcumin on fatty acid synthase expression and enzyme activity in breast cancer cell line SKBR3. Iranian J. Cancer Prev. 2017, 10. [CrossRef]

232. Menendez, J.A.; Vazquez-Martin, A.; Oliveras-Ferraros, C.; Garcia-Villalba, R.; Carrasco-Pancorbo, A.; Fernandez-Gutierrez, A.; Segura-Carretero, A. Analyzing effects of extra-virgin olive polyphenols on breast cancer-associated fatty acid synthase protein expression using reverse-phase protein microarrays. Int. J. Mol. Med. 2008, 22, 433-439. [CrossRef] [PubMed] 
233. Oliveras, G.; Blancafort, A.; Urruticoechea, A.; Campuzano, O.; Gómez-Cabello, D.; Brugada, R.; López-Rodríguez, M.L.; Colomer, R.; Puig, T. Novel anti-fatty acid synthase compounds with anti-cancer activity in HER2 ${ }^{+}$breast cancer. Ann. N. Y. Acad. Sci. 2010, 1210, 86-92. [CrossRef] [PubMed]

234. Rein, M.J.; Renouf, M.; Cruz-Hernandez, C.; Actis-Goretta, L.; Thakkar, S.K.; da Silva Pinto, M. Bioavailability of bioactive food compounds: A challenging journey to bioefficacy. Br. J. Clin. Pharmacol. 2013, 75, 588-602. [CrossRef] [PubMed]

235. Gao, S.; Hu, M. Bioavailability challenges associated with development of anti-cancer phenolics. Mini Rev. Med. Chem. 2010, 10, 550-567. [CrossRef] [PubMed]

236. Watkins, R.; Wu, L.; Zhang, C.; Davis, R.M.; Xu, B. Natural product-based nanomedicine: Recent advances and issues. Int. J. Nanomed. 2015, 10, 6055-6074.

237. Davidov-Pardo, G.; McClements, D.J. Resveratrol encapsulation: Designing delivery systems to overcome solubility, stability and bioavailability issues. Trends Food Sci. Technol. 2014, 38, 88-103. [CrossRef]

238. Seguin, J.; Brullé, L.; Boyer, R.; Lu, Y.M.; Ramos Romano, M.; Touil, Y.S.; Scherman, D.; Bessodes, M.; Mignet, N.; Chabot, G.G. Liposomal encapsulation of the natural flavonoid fisetin improves bioavailability and antitumor efficacy. Int. J. Pharm. 2013, 444, 146-154. [CrossRef] [PubMed]

239. Shaikh, J.; Ankola, D.D.; Beniwal, V.; Singh, D.; Kumar, M.N.V.R. Nanoparticle encapsulation improves oral bioavailability of curcumin by at least 9-fold when compared to curcumin administered with piperine as absorption enhancer. Eur. J. Pharm. Sci. 2009, 37, 223-230. [CrossRef] [PubMed]

240. Paudel, A.; Worku, Z.A.; Meeus, J.; Guns, S.; Van den Mooter, G. Manufacturing of solid dispersions of poorly water soluble drugs by spray drying: Formulation and process considerations. Int. J. Pharm. 2013, 453, 253-284. [CrossRef] [PubMed]

241. Aggarwal, B.B.; Kumar, A.; Bharti, A.C. Anticancer potential of curcumin: Preclinical and clinical studies. Anticancer Res. 2003, 23, 363-398. [PubMed]

242. Bishayee, A. Cancer prevention and treatment with resveratrol: From rodent studies to clinical trials. Cancer Prev. Res. 2009, 2, 409-418. [CrossRef] [PubMed]

243. Ho, C.K.; Choi, S.W.; Fung, M.S.; Benzie, I.F.F. Tea polyphenols: Absorption, bioavailability and potential toxicity. CAB Rev. Perspect. Agric. Vet. Sci. Nutr. Nat. Resour. 2017, 12. [CrossRef]

244. Cheng, F.; Li, W.; Zhou, Y.; Shen, J.; Wu, Z.; Liu, G.; Lee, P.W.; Tang, Y. Admetsar: A comprehensive source and free tool for assessment of chemical admet properties. J. Chem. Inform. Model. 2012, 52, 3099-3105. [CrossRef] [PubMed]

245. Sander, T.; Freyss, J.; Von Korff, M.; Rufener, C. Datawarrior: An open-source program for chemistry aware data visualization and analysis. J. Chem. Inform. Model. 2015, 55, 460-473. [CrossRef] [PubMed]

246. Spratlin, J.L.; Serkova, N.J.; Eckhardt, S.G. Clinical applications of metabolomics in oncology: A review. Clin. Cancer Res. 2009, 15, 431-440. [CrossRef] [PubMed]

247. Zhang, X.; Yap, Y.; Wei, D.; Chen, G.; Chen, F. Novel omics technologies in nutrition research. Biotechnol. Adv. 2008, 26, 169-176. [CrossRef] [PubMed]

248. Del Rio, A.; Da Costa, F.B. Molecular approaches to explore natural and food-compound modulators in cancer epigenetics and metabolism. In Foodinformatics: Applications of Chemical Information to Food Chemistry; Springer International Publishing: Gewerbestrasse, Switzerland, 2014; pp. 131-149.

249. Saeed, M.; Kadioglu, O.; Khalid, H.; Sugimoto, Y.; Efferth, T. Activity of the dietary flavonoid, apigenin, against multidrug-resistant tumor cells as determined by pharmacogenomics and molecular docking. J. Nutr. Biochem. 2015, 26, 44-56. [CrossRef] [PubMed]

250. Paluszczak, J.; Krajka-Kuźniak, V.; Baer-Dubowska, W. The effect of dietary polyphenols on the epigenetic regulation of gene expression in MCF7 breast cancer cells. Toxicol. Lett. 2010, 192, 119-125. [CrossRef] [PubMed]

251. Vanden Berghe, W. Epigenetic impact of dietary polyphenols in cancer chemoprevention: Lifelong remodeling of our epigenomes. Pharmacol. Res. 2012, 65, 565-576. [CrossRef] [PubMed]

(C) 2017 by the authors. Licensee MDPI, Basel, Switzerland. This article is an open access article distributed under the terms and conditions of the Creative Commons Attribution (CC BY) license (http:/ / creativecommons.org/licenses/by/4.0/). 